\title{
Green Stimuli Characteristics and Green Self-Identity Towards Ethically Minded Consumption Behavior with Special Reference to Mediating Effect of Positive and Negative Emotions
}

\author{
Poornima K Gayathree ${ }^{1} \&$ Dinesh Samarasinghe ${ }^{2}$ \\ 1 Department of Marketing Management, Faculty of Commerce and Management Studies, University of \\ Kelaniya, Sri Lanka \\ ${ }^{2}$ Department of Management of Technology, Faculty of Business, University of Moratuwa, Sri Lanka \\ Correspondence: Poornima K Gayathree, Department of Marketing Management, Faculty of Commerce and \\ Management Studies, University of Kelaniya, Dalugama, Kelaniya, Sri Lanka. Tel: 947-1193-6327. E-mail: \\ poornima@kln.ac.lk; poogayathree@gmail.com
}

Received: May 12, 2019 Accepted: May 31, $2019 \quad$ Online Published: June 30, 2019

doi:10.5539/ass.v15n $7 \mathrm{p} 77$

URL: https://doi.org/10.5539/ass.v15n7p77

\begin{abstract}
Research studies related to ethical consumerism has been gaining increasing attention in the last decade due to growing importance with environmental pollution. Research studies pointed out a gap between ethical consumers' behavior and intention which is common in Sri Lanka as well. Hence the study used emotions and self-identity as two key drivers which assist in exploring the intention-behavior gap that has not been researched so far. Therefore the research problem addressed is "whether the positive and negative emotions aroused as a result of consumer subjective evaluation to stimuli, impact on the ethically minded consumption behavior?".

The study focused only on environmental friendly electrical household appliances and the population is the academics and professionals who reside Gampaha and Colombo suburbs and who bought environmental friendly electrical household appliances within the last one year of duration. The unit of analysis is individual consumers and the convenience sampling method used. 200 individual respondents contributed to the study and the data collection was done through a self-administered questionnaire. The study has used Smart PLS 3.2 software and the results showed that the green stimuli characteristics and green self-identity significantly influence ethically minded consumer behavior and only positive emotions act as a significant mediator. Most importantly if the consumer's perceived effectiveness is high, despite the presence of emotions ethically minded consumer behavior will be triggered more. In conclusion, marketers have to use positive emotions when creating the stimuli and should give more priority for assuring the individuals small step for protecting the environment.
\end{abstract}

Keywords: cognitive appraisal theory, self-identity theory, green stimuli characteristics, green self identity, positive emotions, negative emotions, ethically minded consumer behavior, perceived consumer effectiveness

\section{Introduction}

The statistical reports reveal that the global carbon emission has been rising up at a rapid rate and making it worse, forest area also has been drastically reduced (World Bank, n. d.). Therefore, research studies on consumer behavior towards protecting the environment have been increasing since the 1990s' (Khare, 2015). Hence, this research study focus on the ethical consumerism as the broader area which can be defined as, "the practice of purchasing goods and services which has been manufactured in a way with less impact on the society and/or the environment and rejecting the goods and services which will have a harmful impact on the society or the environment.

It has been often concluded by previous researchers that the ethical consumer's behavior does not comply with the attitudes that they report which are observed as common across the globe (Eckhardt, Belk, \& Devinney, 2010; Sudbury-Riley \& Kohlbacher, 2016; Papaoikonomou \& Ryan, 2011). Often the theory adopted in exploring this gap between attitude-behavior is the Theory of Planned Behaviour (TPB) (Khare, 2015; Samarasinghe \& Ahsan, 2014). It has been recognized by the researchers that TPB has several disadvantages; assessing intention to behave without focusing on actual behavior (Hassan, Shiu, \& Shaw, 2014) and ignoring emotions such as anger, fear, hatred, etc. (Ajzen, 2011). Therefore many researchers incorporated emotions as a predictor of intention and 
behavior (Russell, Young, Hardin, \& Robinson, 2017; Wang, 2016). The issue with this method is emotions are aroused as a result of a consumer's subjective evaluation towards the stimuli to which he/she is exposed to (Ellsworth \& Scherer, 2003). This phenomenon has been clearly explained in the cognitive appraisal theories which states that the evaluation of events cause emotions and specified that there is a causal relationship between appraisal dimensions and the emotions (Smith \& Lazarus, 1990; Moors, In Press).

The emotions based research gaining increasing attention in many subject areas since emotions are inevitable in making consumption decisions. So, et al., (2015) has mentioned that there are three main research areas which are available for conducting research in the area of emotions and decision making. The first area is the researching on the interaction between two or more appraisal dimensions which will explain more about the complex decision making. Secondly, identifying new appraisal dimensions which are unique to the certain set of emotions. Thirdly the determination of the impact of appraisal dimensions on the consumer decision making in a given consumer decision-making context. Finally, the psychological processes through which the emotions affect consumer decisions. The study specifies that future research should focus on determining how emotions effect on making effective decisions even though emotions are considered as subjective and impulsive

Therefore the purpose of this research study is determining the impact of consumers psychological processing of stimuli along the dimensions on emotions and how emotions lead to the behavior. Consumers stimuli evaluations and its impact on emotions towards ethical consumerism are still untapped by academics and it would be significant in exploring further about the ethical consumer's behavior (Amatulli et al., 2017).

\section{Research Problem}

The literature on green marketing and ethical consumerism has used different terminologies to measure the behavior of environmentally friendly consumers. Therefore it is important in identifying what constitutes ethical consumption and ethical behavior and the differences between the terms adopted in previous studies. Among the terminologies, many research studies have been carried out regarding the pro-environmental behavior of the consumers. According to Kollmuss \& Agyeman (2002), pro-environmental behavior can be defined as "behavior that consciously seeks to minimize the negative impact of one's actions on the natural and built world (Kollmuss \& Agyeman, 2002, p. 240). While pro-environmental behavior primarily focuses on the consumption with minimal impact on the natural and the built world, ethical consumerism or ethical consumption covers a broader range. According to Sudbury-Riley \& Kohlbacher (2016), ethical consumption includes the following main themes which had been studied by the previous researchers; environmental problems, societal and human justice, consumer boycotts of unethical products and consumer willingness to pay a premium price.

As explained in the introduction, the research articles in the field of ethical consumerism have often used TPB or Theory of Reasons Action (TRA) which were introduced by Ajzen \& Fishbein in 1977 (Khare, 2015; Samarasinghe \& Ahsan, 2014; Carrington et al., 2010). The main criticism regarding the TPB is its applications in explaining the behavior of consumers via the predictors of intention and ignorance of consumer subjective evaluations (Ajzen, 2011). Even though Ajzen (2011) highlighted that beliefs are backed by emotions, recently emotion was used as a predictor of intentions and the behavior (Russell et al., 2017; Wang, 2016). This method is unsuccessful since the consumer emotions are aroused as a result of his/her subjective evaluation of the stimuli (Ellsworth \& Scherer, 2003). This is clearly explained in the cognitive appraisal theories. According to the cognitive appraisal theories, the evaluation of events causes emotions and states that there is a causal relationship between appraisal dimensions and the emotions (Smith \& Lazarus, 1990; Moors, In Press). Further, researchers specified that incorporating the role of emotions would be crucial in explaining the pro-environmental behavior (Rezvania, Janssona, \& Bengtsson, 2017) and George \& Dane (2016) stipulates that incorporating emotions is increasingly added aspect to all the research domains.

According to the justification, the research articles have not been done to determine the significance of the impact of stimuli related to ethical goods on arousing consumer emotions. Therefore the research study identifies Green Stimuli Characteristics (GSC) as a predictor and positive and the negative emotions as mediating the relationship between GSC and Ethically Minded Consumer Behavior. In addition to the dimensions of stimuli evaluation, a persons' stance regarding oneself can also arouse the emotions (Stryker \& Burke, 2000). The reason is the values inherent to each person significantly influence the behavior of that person which is explained under the self-identity theory (Heshmat, 2014). So far the impact of self-identity on the consumers' emotions has not been studied in the previous research studies. The study is specifically confined to the eco-labeled household appliances which are considered as one type of ethical goods.

Doane (2001) specifies that the ethical goods include household goods which are named as eco-labeled household appliances. Collins dictionary defines the household appliances as, "devices or machines, usually 
electrical, that are in your home and which you use to do jobs such as cleaning or cooking" (collinsdictionary, 2017). Household appliances comprise of white goods; refrigerators, freezers, dishwashers, washing machines, and dryers (Mills \& Schleich, 2012) Electrical household appliances consume a massive amount of electricity and water and contribute to carbon emission on daily basis.

According to the Sri Lanka Sustainable Energy Authority, $0.71 \mathrm{~kg} / \mathrm{kWh} \mathrm{CO} 2$ emission takes place by the electricity (Sri Lanka Sustainable Energy Authority, n. d.). Mills \& Schleich (2012) specifies that the highest consumption of electricity is reported by the white goods whilst bulbs and other equipment reports lower values. In Sri Lanka reports of Department of Census and Statistics reports that Sri Lankans spending on durable household goods has increased by $6.3 \%$ in 2016 (Department of Census and Statistics, 2016) which clearly shows us the potential increase of energy consumption in the country. Further the import of household appliances has increased by $41 \%$ in 2015 and $22 \%$ in 2016 (Table 1.4) and Studies reported that the appliances which consume highest amounts of electricity include, refrigerator, air conditioner, washing machine, fan, rice cooker, and iron (Saidur, Masjuki, Jamaluddin, \& Ahmed, 2007). On average $46.2 \%$ of Sri Lankan households possessed a refrigerator and $17.2 \%$ owned a washing machine (Central Bank of Sri Lanka, 2016). Moreover, the highest carbon emission causing aspect within the households is, electricity whilst second place goes to cooking (Yang, Fan, \& Zheng, 2016).

Table 1. Total Electricity Use (CEB+LECO+Self+Off-Grid)(GWh)

\begin{tabular}{cccccc}
\hline User & 2011 & 2012 & 2013 & 2014 & 2015 \\
\hline Domestic & 3928.43 & 4064.74 & 4012.95 & 4051.14 & 4444.75 \\
Domestic Y-Y \% increase & & $3.47 \%$ & $-1.27 \%$ & $0.95 \%$ & $9.72 \%$ \\
\hline
\end{tabular}

(Sri Lanka Sustainable Energy Authority, n.d.)

Table 2. CO2 Emission by Appliance

\begin{tabular}{ccc}
\hline Appliance & Unit & CO2 emissions \\
\hline Air Conditioner & $\mathrm{Kg} / \mathrm{Day}$ & 4.26 \\
Standing Fan & $\mathrm{Kg} / \mathrm{Day}$ & 0.23 \\
Washing Machine & $\mathrm{Kg} / \mathrm{Day}$ & 0.71 \\
Filament Bulbs & $\mathrm{Kg} /$ Day & 0.43 \\
Fluorescent Bulbs & $\mathrm{Kg} /$ Day & 0.09 \\
\hline
\end{tabular}

(Sri Lanka Sustainable Energy Authority, n.d.)

Table 3. Import Values of Household Appliances

\begin{tabular}{cccccccc}
\multicolumn{1}{c}{ US\$ 000 ' } \\
\hline Item & 2010 & 2011 & 2012 & 2013 & 2014 & 2015 & 2016 \\
\hline Home Appliances Imports & 93.2 & 227.9 & 218.5 & 192.2 & 156.4 & 221.0 & 270.7 \\
Year to Year Change $\%$ & & $144.4 \%$ & $-4.1 \%$ & $-12.0 \%$ & $-18.6 \%$ & $41.3 \%$ & $22.5 \%$ \\
\hline
\end{tabular}

(Department of Census and Statistics)

One of the key challenges to the green product marketers is to design communication messages which do not manipulate the customers. It was evident that the customers refuse the manufacturers that mislead them through false messages which highlight the green products (www.greenbiz.com). In developed countries, there is a strong movement towards environmental protection and consuming products which are environmentally friendly. But in developing countries, green buying behavior is not similar to developed countries (Samarasinghe \& Samarasinghe, 2013). In order to increase the reliability of the environmentally friendly products Green Building Council in Sri Lanka has introduced "green labeling system". The reason to introduce is to enhance the demand and supply of green products (http://srilankagbc.org/index.html). This proves that it is challenging to penetrate the green products within Sri Lanka. A most important point to note is that the government of Sri Lanka is in the process of introducing energy efficiency rating to electrical household appliances including LED bulbs and Refrigerators (De Silva, 2016). However, according to a personal interview conducted by the researcher, with an expert in the electrical household appliances has mentioned that "there are different energy ratings available for electrical appliances and each differs according to the evaluation it carries out. When considering refrigerators, inverter technology plays a vital role in energy efficiency. In the Sri Lankan market, there are refrigerators with and without inverters" (Gunawardhana, 2017). This explains that the consumer has a choice among the 
purchasing an electrical appliance with inverter technology or non-inverter technology. According to Gunawardhana (2017), still, there are electrical appliances without inverters circulating in the country. Therefore the study focuses on consumer choice of energy efficient and environmentally friendly electrical appliances.

The global condition of the penetration of green products shows an upward trend (Nielsen, 2014) and most of the countries have introduced green label system to enhance the credibility of the green products (Daily Mirror, 2015). Whilst the global condition marks a positive response towards green products in Sri Lanka it is moving upward at a slower rate. Further research studies in Sri Lanka has provided evidence that the Sri Lankans are emotionally attached to the environment (Samarasinghe \& Samarasinghe, 2013). Thus it would be interesting to investigate the reasons behind positive attitude towards the environment not transferring to the behavior in Sri Lanka. Hence, the problem that the research intends to address is, "whether the positive and negative emotions aroused as a result of consumer subjective evaluation to green stimuli and the green self-identify, impact on the ethically minded consumption behavior".

\section{Conceptualization}

\subsection{Green Stimuli Characteristics and Emotions}

The literature argues that human decisions are always followed by emotional processes even though the consumer runs through a long process to evaluate the feasibility of purchasing a product (Alibage \& Jetter, 2017). Even though the information and detailed description of a particular problem issue regarding a particular situation or a cause are available, the behavior will not be raised unless the affective component not stimulated (Peter \& Honea, 2012). The affective component stimulations have been used by marketers to encourage pro-social behaviors such as donations, waste management, and recycling. Further the researchers have pointed out that the study of the impact of emotions on the pro-social and other consumer behavior domains would be crucial (Cavanaugh et al., 2015) and it is important to know the methods of changing the consumer behavior towards pro-environmental conditions since the belief of each consumer about the impact of different events towards the environment differ (Schwartz \& Loewenstein, 2017).

Emotions can be defined as, a process of creating a perception regarding the events in concern, appraisal of the events based on certain characteristics which are in concerned to the consumer and actions based on the appraisal (Frijda \& Mesquita, 1998). Further, the term emotions have been explained as a cultural and psychobiological variation, which allows the individual to respond dynamically to the changing environmental conditions (Scherer, 2009 b). Most importantly emotions comprise of several characteristics; arousal of emotions are caused by the appraisal of events based on characteristics and considered to be a critical component in the process of emotions creation, emotions are functional and interactional processes, finally, emotions call for action (Frijda \& Mesquita, 1998). Further emotions contain central features such as, arousal of emotions takes place when something striking organisms take place, it has a unique ability to get the person ready to deal with the important events takes place in the humans lives, emotions make the entire person and his subsystems engage in the emotional episodes and it comprises of control precedence (As cited in Scherer, 2009 b). These features allow the researchers to clearly demarcate between emotions and other effects such as moods, preferences, feelings, etc (Scherer, 2009 b).

Emotions comprise of different components; an antecedent event, appraisal of the antecedent event based on characteristics that are relevant to the individual, and finally this appraisal results in response components (Frijda $\&$ Mesquita, 1998). The relationship between the antecedent event, appraisal characteristics and the responses have been highlighted in the emotional theories; basic emotional theories, constructivist emotional theories and appraisal theories of emotions. Out of the three schools of thoughts on the emotional theories the study uses the appraisal theories of emotions to justify the relationship between the appraisal dimensions, emotions and the behavioral responses of the consumers. Accordingly, the fundamental proposition underlying the appraisal theory is that the evaluation of events causes emotions and states that there is a causal relationship between appraisal dimensions and the emotions (Smith \& Lazarus, 1990; Moors, In Press). Even though the researchers argue that the components are multi-directional and nonlinear (Frijda \& Mesquita, 1998; Scherer, 2009 b) it doesn't inhibit studying the appraisal of ethical events by the consumers in a given situation. The theorists take the stance of fixed order among the consequences and the antecedents of emotions. The study only focuses on determining the consumer's emotional appraisal which elicits the emotions in terms of events at a given emotional episode not several cycles of evaluations by the consumer. That means the emotional episode can be divided into subsequent subsets which will perform in a sequential fixed order which allows the researchers to explain the antecedent and the consequences of the emotion (Fernando et al., 2015).

One key antecedent that causes the arousal of the emotion of an individual is the appraisals of events based on 
characteristics which are relevant to the individual appraising the event. The theories of appraisal specifies the dimensions appraisals differently to each other (Fernando et al., 2015) but many of them agreed upon the essential common dimensions; valence, novelty, goal consistency, controllability, expectedness, certainty about implications, causal agency self/someone else/circumstances, fairness, modifiability, involves wellbeing of someone else (Frijda \& Mesquita, 1998), intrinsic pleasantness, outcome probability, discrepancy from expectations, power, adjustment, compatibility with internal and external standards (Scherer, 2009 a).

There are different argument put forward by the researchers about the impact of dimensions of the appraisal on the emotions. There are arguments to support that the overall impact of appraisals on specific emotions (without identifying the specific emotions aroused by each dimension) and vice versa. Measurement of the emotions along the same dimensions is referred to as the fixed set models (Fernando et al., 2015). However, to date, there is no best model suggested by any researcher in terms of measuring emotions and the arguments exist for both sides. The researchers who have introduced variable models have themselves agreed that some dimensions of the appraisal will result in a range of emotions (Fernando et al., 2015) which means there is no universal agreement about the arousal of emotions is fixed or variable. Similar view has been put forward by the study conducted to test the goal relevance and the goal conduciveness on the emotion and specified that goal conduciveness had an effect on a range of emotions (Kreibig, 2017). Therefore the study would assume that the range of emotions would arise across all the dimensions.

The study aims at measuring the impact of the arousal of emotions on the behavior of green products. Ellsworth \& Smith $(1988$ b) specifies that there are three methods to identify dimensions to a study; reduction of dimensions into a minimum, adding more dimensions and principled approach. Out of the three mentioned this study follows a principled approach which mentions that the appraisals will be restricted to a specific set to match with the objective or the subject. Therefore the long list of dimensions mentioned in table 01 would be reduced to dimensions which have been developed into scale by Ellsworth \& Smith (1988 b) which is as mentioned below.

- Pleasantness

- Anticipated effort

- Attentional activity

- Certainty

- Human agency

- Situational agency

- Perceived obstacle

- Importance

- Predictability

Out of the theories introduced to explain the dimensions the study utilizes the definitions provided by the Ellsworth \& Smith (1988 b) and Scherer (2009 a). According to the literature, the appraisal dimensions arouse various emotions (Ellsworth \& Smith, 1988 b; Scherer, 2009 a; Fernando et al., 2015; Frijda \& Mesquita, 1998). However, very little focus has been given to study the effect of appraisal dimensions across the different consumption emotions. Accordingly, the following hypothesis has been developed for determining the green stimuli characteristics on the emotions.

\section{$H_{1 a}:$ Green Stimuli Characteristics have a strong positive influence on the positive emotions}

\section{$H_{1 b}$ : Green Stimuli Characteristics have a strong negative influence on the negative emotions}

\subsection{Green Self-identity and the Emotions}

The behavior of a consumer is the central focus discussed in the marketing subjects and satisfaction of the consumers has been the key to drafting all the marketing offerings. Therefore the consumer behavior researchers primarily targets the consumer as the subject matter of the research studies to investigates what drives the actions of the consumers. It is obvious that the main purpose is to study the drivers underlying the consumption decisions which will assist the organization to draft the strategies to make the product move in the market. The decisions made by consumers are affected by three main factors. Namely personal factors, psychological factors, and social factors. Personal factors are related to the consumers' features, psychological factors are related to the psychological and inner functioning of the consumer and social factors are related to the influences made by the outsiders to the consumption decision of the consumer (Blythe, 2005). Out of the factors affecting the decision as explained above, except social factors both the other factors are related to consumer his or her self. According to that explanation personal features such as demographic, situational involvement and psychological factors such as perception, motives, ability, attitudes, personality (Blythe, 2005) has a direct influence on the consumer 
decisions. That does means "oneself" is clearly the decisive factor for the decisions made.

The concept of self is defined by Baumeister (1999) as, "[t]he individual's belief about himself or herself, including the person's attributes and who and what the self is". This definition highlights three important aspects; individuals beliefs of his/her own, personal attributes and who \& what the person is". According to modern learnings of self, the individual's belief of self or how he explain him/herself according to the past stories and future expectations are referred to as a narrative self. Keeping all the unnecessary things away from the consciousness of an individual of experiencing things that are immediate to them is referred to as minimal self (Gallagher, 2000). Each human life possesses a reason to exist which has been developed throughout his/her lifetime and explained by narratives. However, these narratives are life stories which are connected to events, situations, places, incidents that have taken in the past that one explain about him or herself (Ezzy, 1998). This is called the theory of narrative self-identity and the theory is much popular in the socio-psychological and psychological researchers. However, this theory is less applied into the consumer psychology domain even though the theory is said to comprise of more power than the personality traits, in determining the consumer's unique personality characteristics (McAdams, 2001). This means the narrative theory of self-identity is useful in determining consumers' personality characteristics, values and norms.

In the domain of determining self, most popular theories which are applied to the consumer psychology domain includes self-identity theory and social psychology theory (Hitlin, 2003). Self-identity theory explains that the internal value system of a human that makes him who he is will affect his/her behavior (Heshmat, 2014). The key highlights in the self-identity theory include; the theory presumes that when a human's identity is highly related to self than other identities, the more effect there will be on the behavior and the theory's main focus is the role of the human (e.g. mother, sister, and housewife). The more a certain identity is crucial for defining the self, the more that will impact on the behavior (Stryker \& Burke, 2000). The theory of self-identity was frequently used to predict the ethical consumers buying behavior (Barbarossa, Pelsmacker, \& Moons, 2017) however less focus was given for identifying the impact of self-identity on the arousal of emotions.

It is often argued that the ethical consumers' behavior is not affected by the intentions or else ethical consumers do not walk the talk (Eckhardt et al., 2010; Sudbury-Riley \& Kohlbacher, 2016; Papaoikonomou \& Ryan, 2011). This intention-behavior gap creates a tension within the consumer's mind (Chatzidakis et al., 2004) and this situation can be explained through the prominence a consumer gives to the self-identity. The inconsistency between the self-explanation of the identities (e.g. protection of the environment, charity and donation, etc) and the desired self-identity generates an experience of positive and the negative emotions (Stryker \& Burke, 2000; Stryker, 2004). This situation is clearly explained in the identity discrepancy theory which states that one individual can have more than one identity and inability to comply might cause negative emotions (Marcussen, 2006). Studies have pointed out that more studies on the impact of identity on emotions should be studied including a range of emotional outcomes comparing with present studies (Marcussen \& Gallagher, 2017).

Similar to the explanation of identity discrepancy theories it could be argued that the green consumers' identity that is explained according to a given situation and the desired self-identity, creates emotions which are affecting on the behaviors. That means whether compliance with green identities creates positive emotions and noncompliance leads to negative emotions. According to the literature reviewed, very less attempt has been given to determine the role of green self-identity in the arousal of consumer emotions. Accordingly, the following hypothesis could be derived from the study.

\section{$H_{2 a}:$ Green Self Identity has a strong positive influence on the positive emotions}

\section{$H_{2 b}$ : Green Self Identity has a strong negative influence on the negative emotions}

\subsection{Emotions and Ethically Minded Consumer Behavior}

Emotions can be defined as, a process of creating a perception regarding the events in concern, appraisal of the events based on certain characteristics which are in concerned to the consumer and actions based on the appraisal (Frijda \& Mesquita, 1998). The question is how emotions can be differentiated from the feelings, moods, and attitude. Emotions are enduring than other affective states (Scherer, 2005). There are different views regarding the definition of emotions in the literature. However most of them agree upon common characteristics of emotions such as; arousal of emotions is caused by the appraisal of events based on a characteristics and considered to be a critical component in the process of emotions creation, emotions are functional and interactional processes, finally emotions call for action (Frijda \& Mesquita, 1998) which are used to assess the differences between the emotions and other affective states. The componential theories of appraisal perceive emotions as comprising of the episode and each component links to each other. Still, other theories still take the stance of appraisal and the emotions as independent and appraisal of stimuli lead to the arousal of emotions 
(Scherer, 2005).

Theories of cognitive appraisal highlight that there is an action component of emotion which comes in the form of behavior, changes in the beliefs or the expression (Frijda \& Mesquita, 1998; Stryker \& Burke, 2000; George \& Dane, 2016). The incorporation of emotions in the study of environmental related behavior would be crucial and studying the effect of self-interest would further assist in exploring the intention-behavior gap in the ethical consumerism (Han et al., 2016) and increasing attention has been given by the researchers regarding the impact of emotions on decision making (George \& Dane, 2016). According to the cognitive appraisal theories, the appraisal of stimuli leads to the arousal of emotions which in turn effect on the behavior (Scherer, 2009; Frijda \& Mesquita, 1998). The meaning is, emotions act as a mediator between the appraisal and the behavior. The problem lies in terms of answering the question of how emotions are measured. In answering the question Richins (1997) has identified a range of consumption emotions which has been further reviewed by Laros et al. (2005) and divided the emotions into two aspects; positive and negative emotions. The study will adopt the dimensions used by the Laros et al. (2005). Accordingly, the following hypothesis has been developed by the researcher.

$H_{3 a}$ : Positive Emotions has a strong positive influence on the ethically minded consumer behavior

$H_{3 b}:$ Positive Emotion is a strong mediator between the green stimuli characteristics and the ethically minded consumer behavior

$H_{3 c}:$ Positive Emotion is a strong mediator between the green self-identity and the ethically minded consumer behavior

$H_{4 a}:$ Negative Emotions has a strong negative influence on the ethically minded consumer behavior

$H_{4 b}$ : Negative Emotion is a strong mediator between the green stimuli characteristics and the ethically minded consumer behavior

$H_{4 c}:$ Negative Emotion is a strong mediator between the green self-identity and the ethically minded consumer behavior

\subsection{Perceived Consumer Effectiveness (PCE) as a Moderator}

Consumers' attitude and concerns are influenced by the individual's feelings and beliefs about the issue or the problem of concern. Therefore in an environmentally friendly behavior domain, consumers perception of the control over the problem or the issue leads to the formation of environmental attitudes (Wesley et al., 2012). In order to encourage consumer-centric sustainability, a consumer should be adopting mindful consumption patterns. A mindful consumer cares for self, community, and nature and will shift from acquisitive, repetitive and aspirational consumption patterns. Three of these consumption patterns discuss the overconsumption nature of the consumers (Sheth, Sethia, \& Srinivas, 2012). Therefore in order to encourage the consumers to be mindful of the consumption, one key aspect is to get them convinced for the caring for self, nature and the community issues with regard to overconsumption.

The common problem underlying environmental friendly behavior is less action even though the consumer feels that environmental protection is important. The PCE has been considered as a predictor of environmentally friendly behavior and later researchers have been using the variable as a moderator between the environmental attitudes and the behavior. The definition of PCE specifies that even though a consumer understand the significance of a particular problem or an issue he/she will not take any action in terms of the consumption behavior (Berger \& Corbin, 1992). The consumers' environmental conscious behavior varies across the cultures. Thus, when the consumers do not believe that the environmental issues are within his/her control he/she there is a tendency that the consumer will not take any action (Tam \& Chan, 2017). For an example, when a consumer has an emotional reaction to the environmental issues created by the products under concern, transferring it to the action depends on how far he/she trust that the personal action would be significant to solve the issue. In that circumstance, even though emotions and EMCB relationship are stronger actions would not be taken place. According to the above explanation and the research studies on PCE, it could be argued that the consumer's emotions would be translated to behavior only if the consumer perceives that he/she has the control over the environmental issues under concern. Therefore when the level of PCE is high, the relationship between emotions (PE and NEEMO) and EMCB will be stronger. Less research was conducted to measure whether PCE moderates the relationship between emotions and the behavior even though literature states that PCE differs according to attitudes and feelings. Accordingly, the following hypothesis could be developed based on the literature.

$H_{5}:$ PCE positively moderates the relationship between positive emotions and the ethically minded consumer behavior (When PCE is higher, PE and EMCB relationship will be stronger) 


\section{$H_{6}: P C E$ positively moderates the relationship between Negative Emotions and the ethically minded consumer behavior (When PCE is higher, NEEMO and EMCB relationship will be stronger)}

\subsection{Conceptual Framework}

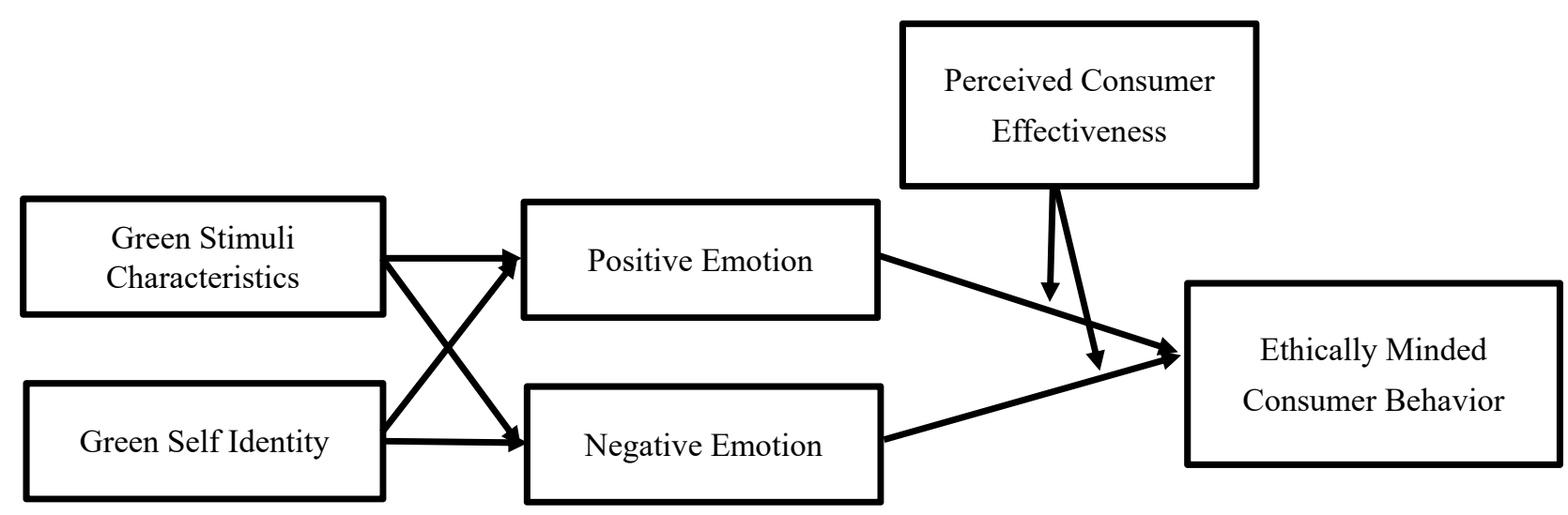

Figure 1. Conceptual Framework

\section{Methods}

\subsection{Research Design, Population and the Unit of Analysis}

This research is placed in the positivistic paradigm, therefore the researcher will be an independent observer. A large sample has been used in the study because this is a cross-sectional study which attempts to sample the users of environmentally friendly electrical household appliances in Sri Lanka. The time horizon of the research is a snapshot. Therefore, this study can be referred to as a cross-sectional study. The population for the study includes the academics and the professionals who reside Gampaha and Colombo suburbs and who have bought environmental friendly electrical household appliances within the last one year of duration. Hence, the unit of analysis of this study is the users of environmentally friendly electrical household appliances in Sri Lanka.

\subsection{Sampling Technique and the Sample Size}

By considering the nature of the target population of the present study it is clear that identifying all the units in the population is impossible. The present study considers its population as the users of environmentally friendly electrical household appliances and it is difficult to calculate how many would be using the environmental friendly electrical household appliances. Therefore convenience sampling has been used to pick the sample. Roscoe (1975) highlights that in multivariate studies samples size of ten or more times than the number of variables shall be considered as adequate (As cited in Sekaran \& Bougie, 2010). Further, to apply more complex analysis using multiple regression, analysis of covariance, or log-linear analysis, which might be performed for more rigorous findings, then a good size sample, would be 200-500 (Israel, 1992). The study, therefore, aims at collecting 200 sample size ( 33 times higher than the six variables of the study) by distributing the questionnaire through online and offline methods.

\subsection{Data Collection and Measures}

Data are collected using primary data collection method and a self-administered questionnaire was used to collect the data. The study uses one predictor; green stimuli characteristics, two mediating variables; positive emotions and negative emotions, a moderator variable: perceived consumer effectiveness and dependent variable; ethically minded consumer behavior.

The study uses two predictors; green stimuli characteristics and green self-identity, two mediating variables; positive emotions and negative emotions, a moderator variable: perceived consumer effectiveness and dependent variable; ethically minded consumer behavior. Green stimuli characteristics items were mainly adopted from a scale developed by Ellsworth \& Smith (1988 a), Ellsworth \& Smith (1988 b) and Gilboa \& Rafaeli (2003). Green self-identity scale was adopted from Whitmarsh \& O’Neill (2010) and emotions scale was adopted from Laros et al. (2005). Perceived Consumer Effectiveness adopted by Straughan \& Roberts (1999) and ethically minded consumer behavior scale was adopted from Sudbury-Riley \& Kohlbacher (2016). All items were measured in seven points Likert scale.

Table 4 explains the demographic characteristics of the sample. Accordingly, the majority are males and females 
also counts to around $48 \%$ of the sample whilst, more than $90 \%$ of the sample is in the age range of $21-40.70 \%$ of the sample earns more than Rs. 40000 a month and around $80 \%$ are Buddhists. In terms of occupation, $39 \%$ of the sample are holding the managerial positions of organizations and $44 \%$ hold the positions of an executive whilst another $37 \%$ are academics in the universities.

Table 4. Demographic Profile

\begin{tabular}{|c|c|c|}
\hline Description & Total & Percentage \\
\hline \multicolumn{3}{|l|}{ Age } \\
\hline $21-30$ & 99 & $49.7 \%$ \\
\hline $31-40$ & 87 & $43.7 \%$ \\
\hline $41-50$ & 11 & $5.5 \%$ \\
\hline $51-60$ & 1 & $.5 \%$ \\
\hline 61 above & 1 & $.5 \%$ \\
\hline \multicolumn{3}{|l|}{ Gender } \\
\hline Female & 97 & 48.7 \\
\hline Male & 102 & 51.3 \\
\hline \multicolumn{3}{|l|}{ Occupation } \\
\hline Accounting Field & 9 & $5 \%$ \\
\hline Administration & 17 & $9 \%$ \\
\hline Academics in Universities & 37 & $19 \%$ \\
\hline Managers in Marketing and Branding Field & 9 & $5 \%$ \\
\hline Managers in the Private Sector & 39 & $20 \%$ \\
\hline Executives in the Private Sector & 88 & $44 \%$ \\
\hline \multicolumn{3}{|l|}{ Income } \\
\hline Below 20000 & 21 & 10.6 \\
\hline $20001-40000$ & 34 & 17.1 \\
\hline $40001-60000$ & 39 & 19.6 \\
\hline $60001-80000$ & 28 & 14.1 \\
\hline $80001-100000$ & 26 & 13.1 \\
\hline 100000 above & 51 & 25.6 \\
\hline \multicolumn{3}{|l|}{ Religion } \\
\hline Buddhist & 164 & 82.4 \\
\hline Catholic & 13 & 6.5 \\
\hline Christian & 10 & 5.0 \\
\hline Hindu & 3 & 1.5 \\
\hline Muslim & 9 & 4.5 \\
\hline
\end{tabular}

\section{Results and Discussion}

\subsection{Results}

\subsubsection{Justification of the Adaptation of PLS-SEM Model}

The model was tested using partial least square structural equation modeling (PLS-SEM) method and Smart PLS 3.0 software has been used for the analysis. In order to adopt CB SEM, several conditions regarding multivariate assumptions, sample size, model complexity should be fulfilled (Chin \& Newsted, 1999). The other approach in addition to CB-SEM for running SEM is, Partial PLS-SEM approach which is adopted when the data are not normal, the sample size is smaller and the model being factor or composites. (Hair et al., 2012). The condition for the sample size for using PLS-SEM is ten times the highest number of constructs directed towards the construct (Hair Jr., 2012 a). As highlighted above the study contains second-order constructs and the maximum number of paths directed towards dimensions are nine whilst, the highest number of paths directed towards a superordinate construct (higher order construct) are, also nine. Accordingly, the study contained a sample size of 200 units, whilst 1 was removed due to the outlier effect. 199 sample units were further processed for SEM analysis.

In analyzing the multivariate assumptions, dependent variable (EMCB) do not satisfy the criteria of normality. The reported Kolmogorov-Smirnov and Shapiro-Wilk test were significant which says that the sample varies 
from the population. Therefore, the first two criteria are satisfied for adopting PLS-SEM. Next is to consider the nature of the constructs (i.e. whether the model is a factor model or a composite model). Accordingly, the study can be referred to as a factor model with reflective indicators. The study contains five constructs including the dependent variable; green stimuli characteristics, positive emotions, negative emotions, perceived consumer effectiveness and ethically minded consumer behavior. Out of these constructs except PCE, all others are second-order constructs. Therefore each second-order construct contains dimensions. Each dimension consists of a set of indicators which are considered as reflective indicators. According to Chin (1998) when the same phenomena are observed by a set of indicators, they are highly related to each other and changing the phenomena require changing the indicators. In this study, each dimension measures one distinctive phenomenon and the indicators are highly correlated. This is similar to all the first order latent variables (dimensions) available. Therefore, the indicators are said to be reflective.

Next question is, whether the first order latent variables are formative or reflective. GSC contains nine first-order latent variables which are mainly adopted from Ellsworth \& Smith (1988 a) and Ellsworth \& Smith (1988 b). There are many researchers which have added dimensions to the GSC whilst the study has only taken nine dimensions adopted by the two research articles specified. Next two second-order latent variables include positive emotions and negative emotions which is adapted from Laros, et al. (2005). Positive emotions comprise of two first-order latent variables and negative emotions comprise of four latent variables. Moreover, EMCB contains five dimensions which explain about the ethical consumerism patterns of a consumer; eco buy, eco boycott, recycle, CSR boycott and pay more. Each second-order construct measures the same phenomena underlying the higher order construct. For example, for GSC researcher, has been continuously adding first order latent constructs and the literature continuously argues that further constructs could be added. Adding or removal of an indicator cannot be done for a formative construct. Similarly to PE, NEEMO, and EMCB, the relationship has been established as reflective. Specially PE and NEEMO comprise of emotions which are highly correlated. Further EMCB dimensions are also reflecting ethical consumerism patterns. Therefore all these are reflective first order latent constructs.

\subsubsection{Process of Analysis}

As explained in the previous section, the study contains multidimensional constructs. The indicators of first-order latent constructs are reflective in nature as justified in the previous section. Further, second-order constructs comprise of, first-order constructs which are considered as reflective as well. In order to continue with the analysis, two-step process suggested by Ringle \& Sarstedt, (2011) and analysis procedure recommended for higher order constructs provided by (Hair Jr, Hukt, Ringle, \& Sarstedt, 2014 a) is adopted. The assessment of the measurement model has been done based on, individual item reliability; internal consistency reliability; convergent validity, and the discriminant validity.

Common method bias test is conducted with the purpose of assessing the bias exist in the measurement method. According to Kock (2015), VIF (Variance Inflation Factor) above 3.3 for each construct indicates the existence of common method bias. According to the statistics provided in table 05, VIF of each construct is less than 3.3 and therefore no common method bias exist in the data set. Further, Herman's single factor score is also calculated by loading all items into one factor and the first-factor loading was 25.37 which is less than $50 \%$.

\subsubsection{Model Fit}

Table 06 provides the model fit indices of the measurement and the structural models. Accordingly, SRMR, $\mathrm{d}_{\mathrm{ULS}}$, $\mathrm{d}_{\mathrm{G}}$ values have been stated with the guidelines provided by the (Henseler, Hubona, \& Ray, Using PLS path modeling in new technology research: updated guidelines, 2016). Hence, the model fit indices of the models fairly meet the criteria.

\subsubsection{Measurement Model Analysis}

Hair Jr et al. (2014 a) specifies that reflective outer measurement models need to be evaluated with reliability (composite reliability and outer loadings) and validity (convergent and discriminant validity). Accordingly, composite reliability is above 0.70 and the factor loadings also are above 0.70 . Ringle et al. (2011) mentioned that in terms of evaluating reflective outer models, convergent and discriminant validity should be assessed. In order to ensure convergent validity, the average variance extracted (AVE) can be used and to assess discriminant validity, Fornell-Larcker criterion can be applied. The convergent validity of the constructs was above 0.5 . Fornell-Larcker criterion says that the AVE of a construct should be higher than the squared value of correlation with another construct (Ringle et al., 2011). AVE is observed along the diagonal of the matrix whilst, that value is compared with other correlation values of the construct, which met the criteria specified above (Please see the table 07 for discriminant validity and 08 for other criteria). 
Table 5. Collinearity Statistics

\begin{tabular}{ccc}
\hline \multirow{2}{*}{ Model } & \multicolumn{3}{c}{ Collinearity Statistics } \\
\cline { 2 - 3 } & Tolerance & VIF \\
\hline GSC & .401 & 2.492 \\
PE & .449 & 2.229 \\
NEEMO & .569 & 1.757 \\
GSI & .538 & 1.857 \\
PCE & .485 & 2.062 \\
\hline
\end{tabular}

\subsubsection{Structural Model Analysis}

Considering the outer measurement is established, the next step is to assess the structural model. The assessment of the structural (inner) model is done in accordance with the criteria specified by Henseler et al. (2016). Ringle et al (2011) specify that R squared and adjusted R squared value is weak, moderate and substantial for $0.25,0.50$ and 0.75 respectively (Hair et al., 2012 b). Further, path coefficients shall also be significant at a 10\% significance level (p-value less than 0.10). According to Ringle et al. (2011), the researcher can select between $10 \%, 5 \%$ or $1 \%$.

Table 6. Model Fit

\begin{tabular}{|c|c|}
\hline Assessment & Criterion \\
\hline \multicolumn{2}{|l|}{ Overall model } \\
\hline \multirow[t]{8}{*}{ test of model fit (Estimated model) } & SRMR $<95 \%$ bootstrap quantile (HI95 of SRMR) \\
\hline & $0.059<(0.085)$ \\
\hline & $\mathrm{d}_{\mathrm{ULS}}<95 \%$ bootsrap quantile (HI95 of $\left.\mathrm{d}_{\mathrm{ULS}}\right)$ \\
\hline & $0.073<(0.153)$ \\
\hline & $\mathrm{d}_{\mathrm{G}}<95 \%$ bootstrap quantile (HI95 of $\mathrm{d}_{\mathrm{G}}$ ) \\
\hline & $0.030<(0.048)$ \\
\hline & $\mathrm{SRMR}<0.08$ \\
\hline & $0.059<(0.08)$ \\
\hline \multicolumn{2}{|l|}{ Measurement model } \\
\hline \multirow{8}{*}{$\begin{array}{l}\text { Confirmatory Factor } \\
\text { model) }\end{array}$} & SRMR $<95 \%$ bootstrap quantile (HI95 of SRMR) \\
\hline & $0.057<(0.086)$ \\
\hline & $\mathrm{d}_{\mathrm{ULS}}<95 \%$ bootsrap quantile (HI95 of $\mathrm{d}_{\mathrm{ULS}}$ ) \\
\hline & $0.068<(0.155)$ \\
\hline & $\mathrm{d}_{\mathrm{G}}<95 \%$ bootstrap quantile (HI95 of $\mathrm{d}_{\mathrm{G}}$ ) \\
\hline & $0.028<(0.045)$ \\
\hline & SRMR $<0.08$ \\
\hline & $0.057<(0.08)$ \\
\hline
\end{tabular}

The $\mathrm{R}^{2}$ value of the structural model incorporating the moderating effect was 0.669 and the adjusted $\mathrm{R}^{2}$ reported as 0.660 . Thus, ethically minded consumer behavior is $66 \%$ explained through the independent variables. Since these values are above 0.50, it can be reported as moderate as per the criteria specified by Ringle et al (2011). The path coefficients and the significance levels are reported in table 09 and 10 which is related to H1a, H1b, $\mathrm{H} 2 \mathrm{a}, \mathrm{H} 2 \mathrm{~b}, \mathrm{H} 3 \mathrm{a}, \mathrm{H} 4 \mathrm{a}, \mathrm{H} 3 \mathrm{~b}, \mathrm{H} 3 \mathrm{c}, \mathrm{H} 4 \mathrm{~b}$, and H4c. The analysis shows that, GSC $->$ PE, GSC $->$ NEEMO, GSI -> PE, GSI -> NEEMO, PE -> EMCB, NEEMO -> EMCB are significant.

The conceptual model comprises of two mediators; Positive Emotions and the Negative Emotions. Hence, the mediation effect analyzed using the guidelines provided by the Hair Jr, et al. (2014 a) and Zhao, et al. (2010). Hair Jr, et al. (2014 a) specifies that, if the direct effect between independent and the dependent variable is not significant, the indirect relationship is meaningless. The analysis reflects that the mediation effect of PE for the GSC to EMCB and GSI to EMCB are significant whilst, the mediation effect of NEEMO for the GSC to EMCB and GSI to EMCB are not significant. Zhao, et al. (2010) specifies that, these types of relationship where direct and indirect effect both significant can be referred to as, complementary relationships. 
Table 7. Discriminant Validity

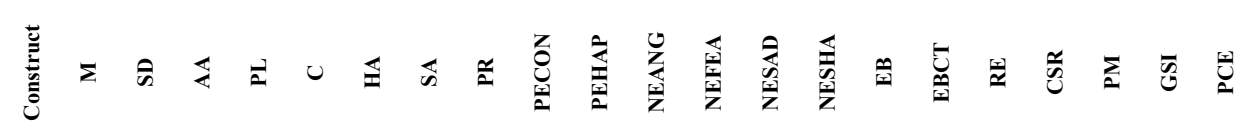

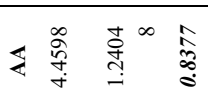

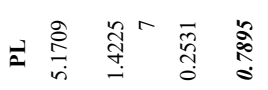

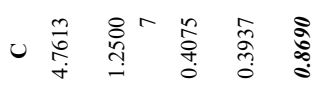

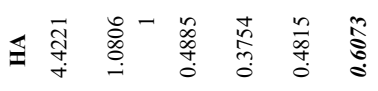

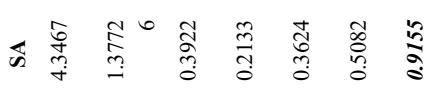

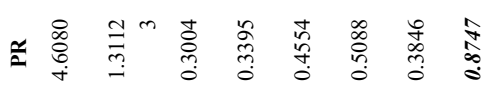

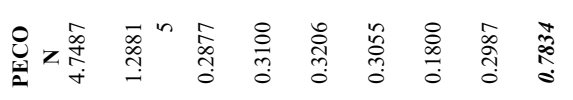

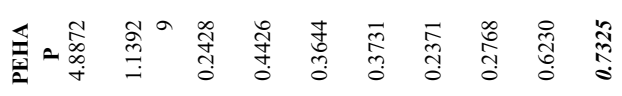

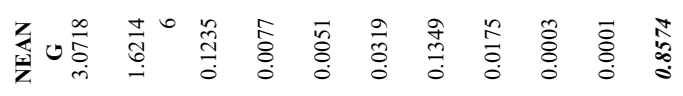

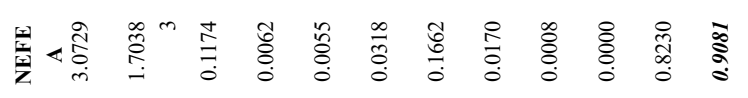

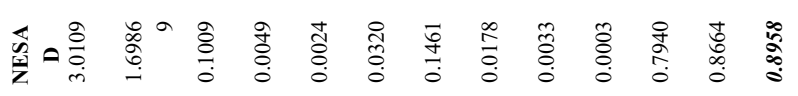

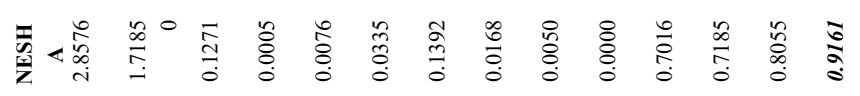

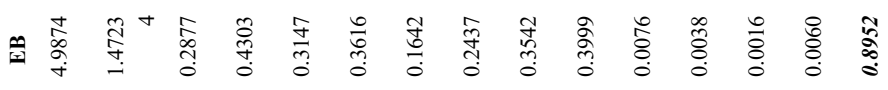

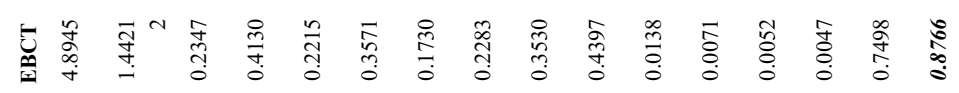

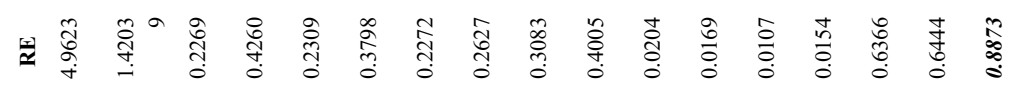

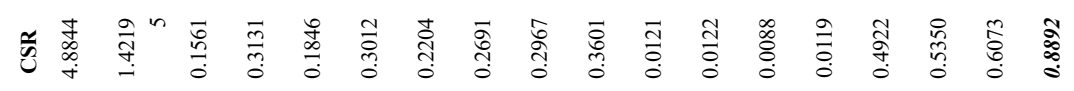

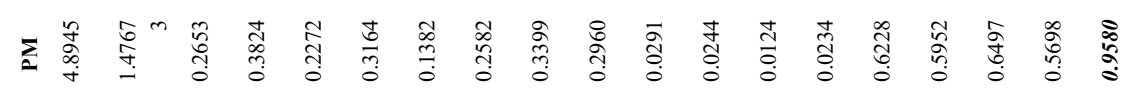

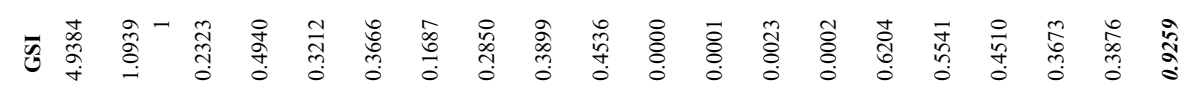

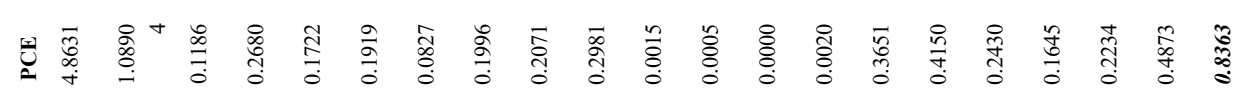


Table 8. Factor Loadings and Reliability of the Manifest Variables and the First Order Latent Constructs

\begin{tabular}{|c|c|c|c|c|c|c|}
\hline $\begin{array}{c}\text { First Order Latent } \\
\text { Construct }\end{array}$ & Item & $\begin{array}{l}\text { Factor } \\
\text { Loading }\end{array}$ & $\begin{array}{l}\text { Cronbach's } \\
\text { alpha }(\alpha)\end{array}$ & $\begin{array}{c}\text { Dijkstra-Henseler's } \\
\text { rho }\left(\rho_{\mathrm{A}}\right)\end{array}$ & $\begin{array}{l}\text { Composite } \\
\text { Reliability }\end{array}$ & $\begin{array}{c}\text { Average Variance } \\
\text { Extracted }\end{array}$ \\
\hline \multirow{2}{*}{$\mathbf{A A}$} & AA1 & 0.914 & \multirow{2}{*}{0.806} & \multirow{2}{*}{0.806} & \multirow{2}{*}{0.912} & \multirow{2}{*}{0.838} \\
\hline & AA2 & 0.917 & & & & \\
\hline \multirow{4}{*}{ PL } & PL1 & 0.855 & \multirow{4}{*}{0.911} & \multirow{4}{*}{0.914} & \multirow{4}{*}{0.937} & \multirow{4}{*}{0.789} \\
\hline & PL2 & 0.898 & & & & \\
\hline & PL3 & 0.892 & & & & \\
\hline & PL4 & 0.909 & & & & \\
\hline \multirow{2}{*}{$\mathbf{C}$} & $\mathrm{C} 1$ & 0.934 & \multirow{2}{*}{0.849} & \multirow{2}{*}{0.850} & \multirow{2}{*}{0.930} & \multirow{2}{*}{0.869} \\
\hline & $\mathrm{C} 2$ & 0.931 & & & & \\
\hline \multirow{5}{*}{ HA } & HA1 & 0.782 & \multirow{5}{*}{0.839} & \multirow{5}{*}{0.845} & \multirow{5}{*}{0.885} & \multirow{5}{*}{0.607} \\
\hline & HA2 & 0.803 & & & & \\
\hline & HA3 & 0.766 & & & & \\
\hline & HA4 & 0.812 & & & & \\
\hline & HA6 & 0.730 & & & & \\
\hline \multirow{2}{*}{ SA } & SA1 & 0.959 & 0008 & 0 & 0.056 & 0015 \\
\hline & $\mathrm{SA} 2$ & 0.955 & 0.900 & 0.909 & 0.900 & 0.915 \\
\hline PR & PR1 & 0.926 & 0858 & 0870 & 0933 & 0875 \\
\hline r K & PR2 & 0.945 & 0.050 & $0.0 / 0$ & 0.953 & 0.013 \\
\hline & PECON1 & 0.799 & & & & \\
\hline PECON & PECON2 & 0.929 & 0.859 & 0.867 & 0.915 & 0.783 \\
\hline & PECON3 & 0.921 & & & & \\
\hline & PEHAP1 & 0.803 & & & & \\
\hline & PEHAP2 & 0.868 & & & & \\
\hline & PEHAP3 & 0.852 & & & & \\
\hline & PEHAP4 & 0.892 & & & & \\
\hline РЕНAР & PEHAP5 & 0.893 & 0.954 & 0.955 & 0.961 & 0.732 \\
\hline & PEHAP6 & 0.901 & & & & \\
\hline & PEHAP7 & 0.871 & & & & \\
\hline & PEHAP8 & 0.817 & & & & \\
\hline & PEHAP9 & 0.798 & & & & \\
\hline & NEANG1 & 0.901 & & & & \\
\hline NE ANG & NEANG4 & 0.934 & 0.945 & 0.948 & 0960 & 0857 \\
\hline 1 VEAT & NEANG5 & 0.941 & נדינס & סדיטס & 0.700 & ו \\
\hline & NEANG7 & 0.928 & & & & \\
\hline & NEFEA1 & 0.962 & & & & \\
\hline NEFEA & NEFEA4 & 0.955 & 0.950 & 0.970 & 0.967 & 0.908 \\
\hline & NEFEA6 & 0.942 & & & & \\
\hline & NESAD1 & 0.946 & & & & \\
\hline NESAD & NESAD5 & 0.945 & 0.942 & 0.955 & 0.963 & 0.896 \\
\hline & NESAD6 & 0.949 & & & & \\
\hline NFSHA & NESHA1 & 0.949 & 0909 & 0930 & 0956 & 0916 \\
\hline NESHA & NESHA3 & 0.965 & 0.909 & 0.930 & 0.956 & 0.910 \\
\hline FB & EMCB1 & 0.949 & 0883 & & & \\
\hline $\mathbf{E} \mathbf{B}$ & EMCB2 & 0.943 & 0.883 & 0.885 & 0.945 & 0.895 \\
\hline FRCT & EMCB3 & 0.944 & 0860 & 0867 & 0034 & 0877 \\
\hline LDC & EMCB4 & 0.929 & 0.000 & 0.007 & 0.934 & 0.011 \\
\hline RF & EMCB5 & 0.944 & 0873 & 0874 & 0940 & 0887 \\
\hline Not & EMCB6 & 0.940 & 0.013 & 0.014 & 0.940 & 0.001 \\
\hline CSR & EMCB7 & 0.943 & 0.875 & 0.875 & 0.941 & 0.889 \\
\hline CSIK & EMCB8 & 0.943 & $0.0 / 5$ & $0.0 / 3$ & 0.941 & 0.009 \\
\hline
\end{tabular}




\begin{tabular}{ccccccc}
\hline PM & EMCB9 & 0.977 & 0.956 & 0.964 & 0.979 & 0.958 \\
& EMCB10 & 0.981 & & & & 0.962 \\
GSI & GSI1 & 0.961 & 0.920 & 0.921 & & 0.9626 \\
& GSI2 & 0.964 & 0.935 & 0.807 & 0.840 & 0.836 \\
\hline
\end{tabular}

Table 9. Hypothesis Testing

\begin{tabular}{ccccccc}
\hline H & & $\beta$ & Standard Deviation & T Statistics & P Values & Decision \\
\hline H1a & GSC -> PE & 0.442 & 0.062 & 7.131 & $0.000^{* *}$ & Supported \\
H1b & GSC - > NEEMO & 0.469 & 0.090 & 5.210 & $0.000^{* *}$ & Supported \\
H2a & GSI -> PE & 0.388 & 0.065 & 5.926 & $0.000^{* *}$ & Supported \\
H2b & GSI - N NEEMO & -0.339 & 0.082 & 4.140 & $0.000^{* *}$ & Supported \\
H3a & PE -> EMCB & 0.213 & 0.074 & 2.871 & $0.004 * *$ & Supported \\
H4a & NEEMO -> EMCB & 0.079 & 0.043 & 1.829 & $0.068^{*}$ & Supported \\
\hline
\end{tabular}

Note: Significant level; $* \mathrm{P}<0.1 ; * * \mathrm{P}<0.05$

Table 10. Mediation Effect Analysis

\begin{tabular}{ccccccc}
\hline H & & $\beta$ & Standard Deviation & T Statistics & P Values & Decision \\
\hline Direct Effects & GSI -> EMCB & 0.218 & 0.080 & 2.742 & $0.006^{* *}$ & Supported \\
Direct Effects & GSC -> EMCB & 0.429 & 0.088 & 4.898 & $0.000^{* *}$ & Supported \\
H3b & GSC -> PE -> EMCB & 0.094 & 0.035 & 2.672 & $0.008^{* *}$ & Supported \\
H3c & GSI -> PE -> EMCB & 0.083 & 0.034 & 2.435 & $0.015^{* *}$ & Supported \\
H4b & GSC -> NEEMO -> EMCB & 0.029 & 0.021 & 1.364 & 0.173 & Not Supported \\
H4c & GSI -> NEEMO -> EMCB & -0.021 & 0.016 & 1.316 & 0.188 & Not Supported \\
\hline
\end{tabular}

Note: Significant level; ${ }^{*} \mathrm{P}<0.1 ; * * \mathrm{P}<0.05$

\subsubsection{Moderator Analysis}

Baron \& Kenny (1986) defines a moderator as a third variable which determines the strength of the relationship between the independent and the dependent variable. The study explains that the strength of the relationship between PE->EMCB and NEEMO->EMCB is determined by PCE. The meaning is when PCE is high, PE->EMCB and NEEMO->EMCB relationship will be stronger. On the other hand, when PCE is Hair Jr, et al (2014 a) specifies that a moderating variable could be continuous or categorical. The authors' further states that, when running a moderator effect using continuous variables, summated scores for the latent constructs should be taken. This has already been received for the latent constructs (GSC, GSI, PE, PCE, NEEMO, and EMCB) of the study when running a structural model. The method is called a two-stage approach which is used together with the product indicator approach to derive the results (Henseler \& Chin, 2010). PLS-SEM with a product indicator approach has been used to assess the moderating effect.

Table 11. Moderator effect analysis

\begin{tabular}{ccccccc}
\hline H & & $\beta$ & Standard Deviation & T Statistics & P Values & Decision \\
\hline Direct Effect & PCE -> EMCB & 0.277 & 0.067 & 4.136 & $0.000^{* *}$ & Supported \\
H5 & PE*PCE->EMCB & -0.131 & 0.035 & 3.734 & $0.000^{* *}$ & Supported \\
Direct Effect & PCE -> EMCB & 0.574 & 0.067 & 8.609 & $0.000^{* *}$ & Supported \\
H6 & NEEMO*PCE -> EMCB & -0.022 & 0.087 & 0.247 & $0.805^{* *}$ & Not Supported \\
\hline
\end{tabular}

Note: Significant level; $* \mathrm{P}<0.1 ; * * \mathrm{P}<0.05$

Moderator relationship is significant for PE->EMCB whilst the moderator relationship is not significant for NEEMO->EMCB relationship. With reference to the coefficient of the moderating effect, it gives a negative value which means, when PCE presents, the relationship between PE and EMCB gets weaker. Further, the moderating relationship between NEEMO->EMCB is not significant.

\subsection{Discussion}

GSC has been measured across nine dimensions and each dimension comprised of items adopted mainly from 
Ellsworth \& Smith (1988 a) Ellsworth \& Smith (1988 b). The appraisal dimensions which assess an event/s (Frijda \& Mesquita, 1998).The results showed that the GSC had a significant influence on the EMCB. The results of the study comply with the previous studies conducted on assessing the relationship between GSC and the behavior. It should be noted that the theory specifies, appraisal dimensions impact on behavior through emotions (Smith \& Lazarus, 1990; Moors, In Press; Ellsworth \& Scherer, 2003). GSC has a direct impact on EMCB despite the fact that theoretical explanation specifies that appraisal dimensions impact behavior through the emotions. This complies with the study conducted by Li, Luo, Zhang, \& Xu (2017) regarding the online privacy behaviors, appraisal dimensions effect on privacy behaviors directly and mediated the effect of emotions also significant (the direct effect is marginally significant). However, the study has not covered fully the appraisal dimensions and restricted itself to several emotions. The study further specifies that cognitive appraisal theories give promising avenues for future research in different fields and context. The present study, therefore, gives a clear picture of the nature of ethical purchasing decisions of Sri Lankans. According to Kreibig, (2017) appraisal of events in terms of goal relevance by the individuals arouses emotions. Hosany (2011) also specifies that cognitive appraisal dimensions have a significant influence on emotions. Hosany (2011) has conducted the study in the field of tourism and specifically focused on the emotional arousal for tourist destinations. This study has not focused on full coverage of emotions and focused only on joy, love and positive surprise. However, the present study carried out has focused on full coverage of emotions including PE and NEEMO. The results of the study match with both the studies specified above which states that appraisal dimensions significantly influence emotions.

Green Self Identity was measured using the scale adopted from Whitmarsh \& O'Neill (2010). The theoretical explanation of self-identity specifies that the internal value system of a human that makes him who he is will affect his/her behavior (Heshmat, 2014). According to the theory of self-identity, more the consumer considers self than other identities the effect on behavior is significant (Stryker \& Burke, 2000). Further according to the theory of identity discrepancy when there is a conflict between the consumer's perception of self and the actual self that will give rise to emotional reactions. According to the results of the study, it showed that GSI has a significant influence on the EMCB. This complies with the theoretical explanation given by Styker et al. (2000) as explained above. Further, this complies with the empirical evidence of Dermody et al. (2017).

However, the study was able to provide a new theoretical insight because the effect of self-identity on PE and NEEMO is significant. It should be noted that the $\beta$ coefficient of the path of GSI->NEEMO is -0.339 which explains that, when a consumers green self-identity is higher less negative emotions will be aroused. This is possible since more of PE whilst less of NEEMO will arouse for consumers with high green self-identity. Dermody et al. (2017) specify that the effect of pro-environmental self-identity on the consumer's sustainable consumption behavior depends according to the context within which the consumer lives and the individual moral reasoning. Further study suggested that carrying out further studies regarding the moral savvy consumers' self-identity would be crucial (Dermody et al., 2017) proving the significance of the study.

As explained above, GSC->EMCB and GSI->EMCB relationships are significant. Further, the relationships between GSC->PE, GSC->NEEMO, GSI->PE, and GSI->NEEMO are also significant. According to Baron \& Kenny (1986) when the direct effect of IV and DV is significant and the mediation path also significant, it is called a partial mediation. The results comply with the study conducted by Li (2017) regarding the online privacy behaviors which state that emotions partially mediated the relationship between appraisals and the behavioral intention. However, the study has incorporated only positive emotions and has neglected the negative emotions. Hosany (2011) also specifies that appraisal dimensions has a significant influence on emotions and did not assess the effect of emotions on the behavior. This explains that the consumers' evaluation of green stimuli effect on arousing positive emotions which in turn impact on the ethically minded purchasing decisions.

The literature on GSI and its impact on emotions was not available and the results showed that the PE partially mediates the relationship between GSI and EMCB. Therefore this becomes one key theoretical contribution of the study which states that the consumers' consideration of self, impact significantly on the ethical purchasing decisions. However according to the analysis of data, only positive emotions mediates the relationship between GSI and EMCB, but NEEMO does not reflect as a significant mediator. An important point to note here is, higher the consumer's consideration on green self-identity, its impact on PE is higher and lower on NEEMO.

Baron \& Kenny (1986) specifies that a moderator is a third variable which strengthens or weakens the relationship between the IV and DV. Accordingly, the study hypothesized that the PCE which determines the consumer's consideration of the effect of his/her actions to solve the matter in concern, the effect on the strength of the relationship between PE->EMCB and NEEMO->EMCB. The analysis of data specifies that PCE weakens the relationship between PE and EMCB whilst PCE do not affect significantly on the relationship between 
NEEEMO and EMCB. Berger \& Corbin (1992) conducted a study to determine the relationship between attitude and the behavior and it was proved that the PCE significantly impact to strengthen the relationship between the IV and DV. On the other hand, Kim (2011) specifies that PCE did not have any effect on the relationship between attitude and behavior whilst the interaction term reported a negative value. Hence, the two studies Berger \& Corbin (1992) and Kim (2011) has given two extreme findings for the moderating effect of PCE on the relationship between attitude and behavior.

The present study shows that when PCE is higher, PE and EMCB relationship is weaker. The possible explanation for this finding is when the consumer perceives that the effect of his/her actions on the environmental issues is higher, the presence of emotions to effect on the ethically minded consumer behavior is less. That is, consumers who believe to exist high PCE, emotions are not required to enforce the ethical purchasing decisions. This gives rise to a new contribution to the cognitive appraisal theories which states that the emotions significantly affect the behavioral aspect of the consumers. The effect of emotions on behavior depends on the control behavior of the consumers.

\section{Managerial Implications}

The study gives a critical contribution to the practitioners, i.e. marketers of ethical products and services since the marketers involved in designing the marketing messages via 7 P's which becomes the stimuli to the consumers. Therefore when designing the marketing messages to the ethical products and services, marketers must ensure that the consumer's emotions are triggered. Especially positive emotions play a vital role in enforcing the ethically minded consumption decisions. Therefore, the marketing messages should be designed in such a way that the consumer's positive emotions are triggered to ensure that, the ethical products and services are purchased. In accordance with the marketing literature, one of the stimuli that come under the "product" is the labeling that has been used as one main marketing aspect. The label includes all the details regarding the product, such as brand name, weight, ingredients, nutrition details, company name, and address and the quality certifications. Recently the government has made a decision to incorporate energy efficient labeling system to household appliances which will assist the customers to make better purchasing decisions (Silva, 2016). Further, the Ministry of Power and Energy reports that the government is planning to conduct an energy survey in 2019 with the objective of preserving energy (Ministry of Power and Renewable Energy, 2017). Therefore, it could be anticipated that the energy efficient appliances will be marketed with an effective mechanism and a valid certification about energy efficiency in the future.

According to the literature, one key issues is ethical consumers do not walk their talk (Carrington et al., 2010) and many studies have been carried out to identify why the consumers are not complying with the intention to purchase the ethical products and services (Eckhardt et al., 2010; Sudbury-Riley \& Kohlbacher, 2016; Papaoikonomou \& Ryan, 2011). One issue with many of these studiesis jumping into conclusions with future intent to purchase. Hence Sudbury et al. (2016) have developed a new scale to determine the behavior related to the ethical consumerism of the ethical consumers. Especially the scale considers the actual purchasing behavior of the consumers than assessing the intentions. Therefore, the results showed that consumers ethically minded decisions are highly influenced by continuous appraisals, self-identity, and emotions. The marketers must ensure that the consumers with high self-directed focus are addressed with a focus on the impact of not transferring intentions to behavior. The reason is highly self-directed consumers tend to arouse emotional feelings when his/her actual behavior differs from the perceived behavior, which will induce ethically minded purchasing decisions.

It was hypothesized that the relationship between emotions and the ethically minded consumer behavior moderated by perceived consumer effectiveness. As explained previously, perceived consumer effectiveness was explained as the level of consumer's consideration of the significance of the impact of his/her actions to solve environmental problems. According to the findings it was observed that the presence of PCE weakens the relationship between emotions and the EMCB. Especially this effect is significant for PE->EMCB than NEEMO->EMCB. This gives rise to clear implications for practitioners because ensuring in the marketing messages that the individual's impact is significant towards the solving of environmental issues, will assist to influence the ethically minded purchasing decisions despite the fact that emotions presence or not. According to the explanation, it is clear that marketing messages should be designed in such a way consumers which will ensure the consumers about their small impact in protecting the environment whilst positive emotions are triggered regarding the results of protecting the environment.

\section{Limitations and Directions for Future Research}

Ethical consumers differ according to the significance each would allocate regarding environmental protection. 
Some consumers would give significant weight whilst another would give low weight. Berger \& Corbin (1992) has conducted a research on the significance of PCE as a moderator in attitude-behavior relationship and when the analysis is conducted, the researcher separately analyzed for high PCE and low PCE separately. The reason behind is the impact of the results of PCE to impact environmentally friendly behavior vary according to the relative weight the consumer allocates to environmental friendliness when making the purchasing decision. However PCE is one moderator used in the study, but when carrying out future research regarding the emotional impact of the consumers in making the ethical purchasing decisions levels of significance given for environmental friendliness also should be considered. This will give more valid findings which could be used when making decisions by the business organizations.

As explained earlier, the environmental considerations in making purchasing decisions and emotional arousal differ with personal factors. Further, it depends on the personal meanings and interpretations attached to the environmental issues. The culture within which the consumer lives and religious beliefs will determine the attachment of individuals to the environment. Depending on these factors, each consumer's interpretation of the environmental issues is different. Therefore future studies should be conducted regarding the cultural interpretations, nature, and meanings attached to the environmental issues by the Sri Lankan consumers with qualitative studies. This will assist in exploring more deeply into the consumer's behavior of ethical consumption patterns.

In addition to the qualitative studies, experimental studies could be conducted to determine the consumer's evaluation of positive and negative advertising messages along appraisal dimensions and their impact on EMCB through positive and negative emotions. Even though experimental studies have already been conducted regarding the ad content, it would be important to carry out the study to the Sri Lankan context. This would allow analyzing the impact within a controlled environment which will elicit which emotions would be most influential in ethical consumption decisions. Further, the studies on ethical consumptions should be carried out a wider audience (than professionals and academics). Finally, longitudinal studies are required to assess Sri Lankans behavior towards ethical consumption decisions.

\section{References}

Adams, R. (1990). Green Consumerism and the Food Industry: Early Signs of Big Changes to Come. British Food, 92(9), 11-14. https://doi.org/10.1108/00070709010142685

Ajzen, I. (2005). Attitudes, Personality and Behaviour (2nd ed.). Open University Press. Retrieved from https://psicoexperimental.files.wordpress.com/2011/03/ajzeni-2005-attitudes-personality-and-behaviour-2nd -ed-open-university-press.pdf

Ajzen, I. (2011). The theory of planned behaviour: Reactions and reflections. Psychology \& Health, 26(9), 1113-1127. https://doi.org/10.1080/08870446.2011.613995

Akenji, L. (2014). Consumer scapegoatism and limits to green consumerism. Journal of Cleaner Production, 63, 13-23. https://doi.org/10.1016/j.jclepro.2013.05.022

Albouy, J. (2017). Emotions and prosocial behaviours: A study of the effectiveness of shocking charity campaigns. Recherche et Applications en Marketing, 1-22. https://doi.org/10.1177/2051570716689241

Alibage, A., \& Jetter, A. (2017). Drivers of Consumers' Emotional Engagement with Everyday Products: An Intensive Review of the Literature and an Attempt to Conceptualize the Consumer-Product Interactions Within the Emotional Design Process. Student Research Symposium 2017. Portland State University. Retrieved from http://pdxscholar.library.pdx.edu/studentsymposium/2017/Presentations/10

Alvarado-Herrera, A., Bigne, E., Aldas-Manzano, J., \& Curras-Perez, R. (2015). A Scale for Measuring Consumer Perceptions of Corporate Social Responsibility Following the Sustainable Development Paradigm. Journal of Business Ethics. https://doi.org/10.1007/s10551-015-2654-9

Amatulli, C., Angelis, M. D., Peluso, A. M., Soscia, I., \& Guido, G. (2017). The Effect of Negative Message Framing on Green Consumption: An Investigation of the Role of Shame. Journal of Business Ethics. https://doi.org/10.1007/s10551-017-3644-x

American Marketing Association. (n. d.). Retrieved October 9, 2016, from https://www.ama.org/resources/Pages/ Dictionary.aspx?dLetter $=\mathrm{B}$

American Psychological Association. (n. d.). Retrieved fromhttp://www.apa.org/topics/personality/

Arachchi, R. S., Yajid, M. S., \& Khatibi, A. (2015). Eco-Tourism Practices in Sri Lankan Eco Resorts: An Analysis of Satisfaction and Behavioral Intention of Eco-Tourists. International Journal of Business and 
Social Science, 6(10), 211-226.

Ariffin, S., Yusof, J. M., Putit, L., \& Shah, M. I. (2016). Factors Influencing Perceived Quality and Repurchase Intention Towards Green Products. Procedia Economics and Finance, 37, 391-396. https://doi.org/10.1016/S2212-5671(16)30142-3

Bagozzi, R. P., Gopinath, M., \& Nyer, P. U. (1999). The Role of Emotions in Marketing. Academy of Marketing Science Journal, 27(2), 184-206. https://doi.org/10.1177/0092070399272005

Bagozzi, R. P., Sekerka, L. E., \& Sguera, F. (2018). Understanding the consequences of pride and shame: How self-evaluations guide moral decision making in business. Journal of Business Research, 84, $271-284$. https://doi.org/10.1016/j.jbusres.2017.11.036

Bamunusinghe, R. (2014). Retrieved from http://www.sundaytimes.lk/141207/business-times/todays-middleclass-an-insight-into-the-contemporary-middle-class-of-sri-lanka-130841.html

Barbarossa, C., Pelsmacker, P. D., \& Moons, I. (2017). Personal Values, Green Self-identity and Electric Car Adoption. Ecological Economics, 140, 190-200. https://doi.org/10.1016/j.ecolecon.2017.05.015

Baron, R. M., \& Kenny, D. A. (1986). The Moderator-Mediator Variable Distinction in Social Psychological Research: Conceptual, Strategic, and Statistical Considerations. Journal of Personality and Psychology, 51(6), 1173-1182. https://doi.org/10.1037/0022-3514.51.6.1173

Barreiro, P. L., \& Albandoz, J. P. (2001). Population and sample. Sampling techniques. University of Seville.

Batkoskaa, L., \& Koseskaa, E. (2012). The Impact of Cognitive Learning on Consumer Behaviour. Procedia Social and Behavioral Sciences, 44, 70-77. https://doi.org/10.1016/j.sbspro.2012.05.006

Baumeister, R. F. (1999). Self-concept, self-esteem, and identity. Retrieved from https://research-srttu.wikispaces.com/file/view/self+concept+\%2B+self+esteem+and+identity.pdf

Ben-Gal, I. (2005). Outlier Detection. In O. Maimon, \& L. Rockach (Eds.), Data Mining and Knowledge Discovery Handbook: A Complete Guide for Practitioners and Researchers (pp. 1-15). Kluwer Academic Publishers. https://doi.org/10.1007/0-387-25465-X_7

Berger, I. E., \& Corbin, R. M. (1992). Perceived Consumer Effectiveness and Faith in Others as Moderators of Environmentally. Journal of Public Policy \& $\quad$ Marketing, $11(2), \quad 79-89$. https://doi.org/10.1177/074391569201100208

Berger, I. E., \& Corbin, R. M. (1992). Perceived Consumer Effectiveness and Faith in Others as Moderators of Environmentally Responsible Behaviors. Journal of Public Policy \& Marketing, 11(2), 79-89. https://doi.org/10.1177/074391569201100208

Bhuian, S. N., Sharma, S. K., Butt, I., \& Ahmed, Z. U. (2018). Antecedents and pro-environmental consumer behavior (PECB): the moderating role of religiosity. Journal of Consumer Marketing, 35(3), $287-299$. https://doi.org/10.1108/JCM-02-2017-2076

Bissing-Olson, M. J., Fielding, K. S., \& Iyer, A. (2016). Experiences of pride, not guilt, predict pro-environmental behavior when pro-environmental descriptive norms are more positive. Journal of Environmental Psychology, 45, 145-153. https://doi.org/10.1016/j.jenvp.2016.01.001

Blythe, J. (2005). Essentials of Marketing (3rd ed.). Essex: Pearson Education Limited. Retrieved from http:// faculty.mu.edu.sa/public/uploads/1349950041.2854Essentials_of_Marketing_3rd_Ed_0273693581.pdf

boundless.com. (n. d.). Retrieved August 30, 2016, from https://www.boundless.com/management/textbooks/bou ndless-management-textbook/organizational-behavior-5/drivers-of-behavior-44/defining-values-229-3989/

Bray, J., Johns, N., \& Kilburn, D. (2011). An Exploratory Study into the Factors Impeding Ethical Consumption. Journal of Business Ethics, 98(4), 597-608. https://doi.org/10.1007/s10551-010-0640-9

Breckler, S. J. (1984). Empirical Validation of Affect, Behavior, and Cognition as Distinct Components of Attitude. Journal of Personality and Social Psychology, 47(6), 1191-1205. https://doi.org/10.1037//0022-3514.47.6.1191

Brosch, T., Pourtois, G., \& Sander, D. (2010). The perception and categorization of emotional stimuli: A review. Cognition and Emotion, 24(3), 377-400. https://doi.org/10.1080/02699930902975754

Brown, K., \& Kasser, T. (2005). Are Psychological And Ecological Well-Being Compatible? The Role of Values, Mindfulness, and Lifestyle. Social Indicators Research, 74, 349-368. https://doi.org/10.1007/s11205-004-8207-8 
Businessdictionary.com. (n. d.). Retrieved September 24, 2016, from http://www.businessdictionary.com/ definition/perceived-quality.html

Byrne, B. M. (2008). Structural Equation Modeling with EQS: Basic Concepts, Applications, and Programming. New York: Psychology Press.

Carrington, M., Neville, B., \& Whitwell, G. (2010). Why Ethical Consumers Don't Walk Their Talk: Towards a Framework for Understanding the Gap Between the Ethical Purchase Intentions and Actual Buying Behaviour of Ethically Minded Consumers. Journal of Business Ethics, 97, 139-158. https://doi.org/10.1007/s10551-010-0501-6

Caruana, R., Carrington, M. J., \& Chatzidakis, A. (2016). "Beyond the Attitude-Behaviour Gap: Novel Perspectives in Consumer Ethics": Introduction to the Thematic Symposium. Journal of Business Ethics, 136, 215-218. https://doi.org/10.1007/s10551-014-2444-9

Cavanaugh, L. A., Bettman, J. R., \& Luce, M. F. (2015). Feeling Love and Doing More for Distant Others: Specific Positive Emotions Differentially Affect Prosocial Consumption. Journal of Marketing Research, 52(5), 657-673. https://doi.org/10.1509/jmr.10.0219

Central Bank of Sri Lanka. (2016). Sri Lanka Socio Economic Data 2016. Colombo: Central Bank of Sri Lanka.

Chang, Y. S., \& Fang, S. R. (2013). Antecedents and distinctions between online trust and distrust: Predicting high-and low-risk Internet behaviors. Journal of Electronic Commerce Research, 14(2), 149.

Chatzidakis, A., Hibbert, S., Mittusis, D., \& Smith, A. (2004). Virtue in Consumption? Journal of Marketing Management, 20(5-6), 526-543. https://doi.org/10.1362/0267257041323972

Chatzidakis, A., \& Lee, M. (2012). Anti-Consumption as the Study of Reasons against. Journal of Macromarketing, 1-14. https://doi.org/10.1177/0276146712462892

Chatzidakis, A., Hibbert, S., Mittusis, D., \& Smith, A. (2004). Virtue in Consumption? Journal of Marketing Management, 5-6, 526-543. https://doi.org/10.1362/0267257041323972

Chatzisarantis, N. L., \& Hagger, M. S. (2008). Influences of personality traits and continuation intentions on physical activity participation within the theory of planned behaviour. Psychology and Health, 23(3), 347-367. https://doi.org/10.1080/14768320601185866

Chaudary, S., Zahid, Z., Shahid, S., Khan, S., \& Azar, S. (2016). Customer perception of CSR initiatives: its antecedents and consequences. Social Responsibility J., 12(2). https://doi.org/10.1108/SRJ-04-2015-0056

Chaudhuri, A., \& Holbrook, M. B. (2001). The Chain of Effects from Brand Trust and Brand Affect to Brand Performance: The Role of Brand Loyalty. Journal of Marketing, 65, 81-93. https://doi.org/10.1509/jmkg.65.2.81.18255

Chen, Y., \& Chang, C. (2012). Enhance green purchase intentions: The roles of green perceived value, green perceived risk, and green trust. Management Decision, 50(3), 502-520. https://doi.org/10.1108/00251741211216250

Chen, Y., \& Chang, C. (2013). Towards green trust: The influences of green perceived quality, green perceived $\begin{array}{lllll}\text { risk, and green satisfaction. } & \text { Management }\end{array}$ https://doi.org/10.1108/00251741311291319

Cherrier, H., Black, I. R., \& Lee, M. (2011). Intentional non-consumption for sustainability. Journal of Marketing, 45(11/12), 1757-1767. https://doi.org/10.1108/03090561111167397

Cheung, R., Lam, A. Y., \& Lau, M. M. (2015). Drivers of green product adoption: The role of green perceived value, green trust and perceived quality. Journal of Global Scholars of Marketing Science: Bridging Asia and the World, 25(3), 232-245. https://doi.org/10.1080/21639159.2015.1041781

Chin, W. W. (1998). The Partial Least Squares Approach to Structural Equation Modeling. In G. A. Marcoulides (Ed.), Modern Methods for Business Research (pp. 295-336). London: Lawrenece Erlbaum Associates. Retrieved from https://www.researchgate.net/profile/Wynne_Chin/publication/232569511_The_Partial_ Least_Squares_Approach_to_Structural_Equation_Modeling/links/0deec533e0f7c00f59000000.pdf

Chin, W. W., \& Newsted, P. R. (1999). Structural Equation Modeling Analysis with Small Samples Using Partial Least Square. In R. H. Hoyle (Ed.), Statistical Strategies for Small Sample Research (pp. 307-341). London: Sage Publications. Retrieved from file://D:/MBA\%20Colombo/Restarting\%20Thesis/Data\%20Analysis/ Artciles\%20for\%20Analysis/1999ChinandNewstedPLSsmallsamplebookchapter.pdf 
Cho, J. (2006). The Mechanism of Trust and Distrust Formation and Their Relational Outcomes. Journal of Retailing, 82(1), 25-35.https://doi.org/10.1016/j.jretai.2005.11.002

Choi, E. J., \& Kim, S. (2013). The Study of the Impact of Perceived Quality and Value of Social Enterprises on Customer Satisfaction and Re-Purchase Intention. International Journal of Smart Home, 239-252. Retrieved from http://www.sersc.org/journals/IJSH/vol7_no1_2013/22.pdf

Churchill, Jr., G. A. (1979). A Paradigm for Developing Better Measures of Marketing Constructs. Journal of Marketing Research, 16(1), 64-73. https://doi.org/10.1177/002224377901600110

Cohen, J., Pant, L., \& Sharp, D. (1993). A Validation and Extension of a Multidimensional Ethics Scale. Journal of Business Ethics, 12(1), 13-26. https://doi.org/10.1007/BF01845782

collinsdictionary. (2017). Retrieved from https://www.collinsdictionary.com/dictionary/english/household-applia nces

Connolly, J., \& Prothero, A. (2008). Green Consumption: Life-politics, risk and contradictions. Journal of Consumer Culture, 8, 117-145. https://doi.org/10.1177/1469540507086422

Cooper-Martin, E., \& Holbrook, M. B. (1993). Ethical Consumption Experiences and Ethical Space. Advances in Consumer Research, 20, 113-118.

Creswell, J. W. (2008). Research Design: Qualitative, Quantitative, and Mixed Methods Approaches. Los Angelese: Sage Publication.

D'Souza, C., Taghian, M., \& Khosla, R. (2007). Examination of environmental beliefs and its impact on the influence of price, quality and demographic characteristics with respect to green purchase intention. Journal of Targeting, Measurement and Analysis for Marketing, 15(2), 69-78. https://doi.org/10.1057/palgrave.jt.5750039

Daily Mirror. (2015, October 14). Retrieved May 27, 2016, from http://www.dailymirror.lk/91325/go-greensri-lanka

Darke, P. R., \& Ritchie, R. J. (2007). The Defensive Consumer: Advertising Deception, Defensive Processing, and Distrust. Journal of Marketing Research, XLIV, 114-127. https://doi.org/10.1509/jmkr.44.1.114

De Silva, C. (2016, February 19). Retrieved from http://www.ft.lk/article/526349/Govt--to-introduce-MinimumEnergy-Performance-Standards-soon

Dell, R. B., Holleran, S., \& Ramakrishnan, R. (2002). Sample Size Determination. Institute for Laboratory Animal Research, 43, 207-213. https://doi.org/10.1093/ilar.43.4.207

Department of Census and Statistics. (2016). Household Income and Expenditure Survey - 2016. Colombo: Department of Census and Statistics, Ministry of National Policies and Economic Affairs.

Department of Census and Statistics. (2017). Status of Sustainable Development Goals Indicators in Sri Lanka. Colombo: Department of Census and Statistics. Retrieved from http://www.statistics.gov.lk

Dermody, J., Koenig-Lewis, N., Zhao, A. L., \& Hanmer-Lloyd, S. (2017). Appraising the influence of pro-environmental self-identity on sustainable consumption buying and curtailment in emerging markets: Evidence from China and Poland. Journal of Business Research. https://doi.org/10.1016/j.jbusres.2017.09.041

Doane, D. (2001). New Economics Foundation report for The Co-operative Bank, New Economics Foundation; taking flight: the rapid growth of ethical consumerism The Ethical Purchasing Index 2001. Retrieved from http://b.3cdn.net/nefoundation/dcca99d756562385f9_xtm6i6233.pdf

Drake, C., \& Radford, S. K. (2018). "[Softly Assembled] Gender Performance Through Products: Four Practices Responding to Masculine and Feminine Codes in Product Design. Consumer Culture Theory, 123-144. https://doi.org/10.1108/S0885-211120180000019008

Durbin, J., \& Watson, G. S. (1950). Testing for Serial Correlation in Least Squares Regression: I. Biometrika, 37(3/4), 409-428. https://doi.org/10.1093/biomet/37.3-4.409

Dzialo, L. (2017). The feminization of environmental responsibility: A quantitative, cross-national analysis. Environmental Sociology. https://doi.org/10.1080/23251042.2017.1327924

Easterby-Smith, M., Thorpe, R., \& Lowe, A. (2002). Management Research: An Introduction (2nd ed.). London: Sage Publications. 
Eckhardt, G., Belk, R., \& Devinney, T. (2010). Why don't consumers consume ethically? Journal of Consumer Behaviour, 9, 426-436. https://doi.org/10.1002/cb.332

EIT. (n. d.). Retrieved September 24, 2016, from http://www.climate-kic.org/case-studies/defining-carbon-foot prints-of-tourism-packages/

Ellsworth, P. C., \& Scherer, K. R. (2003). Appraisal processes in emotion. In Handbook of affective sciences (pp. 572-594). V595. Retrieved from http://people.ict.usc.edu/ gratch/CSCI534/Readings/EllsworthScherer03. PDF

Ellsworth, P. C., \& Smith, C. A. (1988 a). From Appraisal to Emotion: Differences among Unpleasant Feelings. Motivation and Emotion, 12(3), 271-302. https://doi.org/10.1007/BF00993115

Ellsworth, P. C., \& Smith, C. A. (1988 b). Shades of Joy: Patterns of Appraisal Differentiating Pleasant Emotions. Cognition and Emotion, 2(4), 301-331. https://doi.org/10.1080/02699938808412702

Ezzy, D. (1998). Theorizing Narrative Identity: Symbolic interactionism and Hermeneutics. The Sociological Quarterly, 39(2), 239-252. https://doi.org/10.1111/j.1533-8525.1998.tb00502.x

Fernando, J. W., Kashima, Y., \& Laham, S. M. (2015). Alternatives to the fixed-set model: A review of appraisal models of emotion. Cognition and Emotion. https://doi.org/10.1080/02699931.2015.1074548

Field, A. (2009). Discovering Statistics Using SPSS (3rd ed.). London: SAGE Publications Ltd.

Flowers, P. (2009). Research Philosophies - Importance and Relevance.

Fraj, E., \& Martinez, E. (2006). Environmental values and lifestyles as determining factors of ecological consumer behaviour: An empirical analysis. Journal of Consumer Marketing, 133-144. https://doi.org/10.1108/07363760610663295

Frijda, N. H., \& Mesquita, B. (1998). The Analysis of Emotion: Dimensions of Variation. In M. F. Mascolo, \& S. Griffin (Eds.), What Develops in Emotional Development (pp. 274-295). New York: Plennum Press. https://doi.org/10.1007/978-1-4899-1939-7_11

Gallagher, S. (2000). Philosophical conceptions of the self: implications for cognitive science. Trends in Cognitive Sciences, 4(1), 14-21. https://doi.org/10.1016/S1364-6613(99)01417-5

Gallarza, M. G., Gil-Saura, I., \& Holbrook, M. B. (2011). The value of value: Further excursions on the meaning and role of customer value. Journal of Consumer Behaviour, 10, 179-191. https://doi.org/10.1002/cb.328

George, J. M., \& Dane, E. (2016). Affect, emotion, and decision making. Organizational Behavior and Human Decision Processes, 136, 47-55. https://doi.org/10.1016/j.obhdp.2016.06.004

Gilg, A., Barr, S., \& Ford, N. (2005). Green consumption or sustainable lifestyles? Identifying the sustainable consumer. Futures, 37, 481-504. https://doi.org/10.1016/j.futures.2004.10.016

Glasow, P. A. (2005). Fundamentals of Survey Research Methodology. McLean, Virginia.

Grossman, M. G., \& Krueger, A. B. (1995). Economic Growth and the Environment. The Quarterly Journal of Economic, 110(2), 353-377. https://doi.org/10.2307/2118443

Gunawardhana, A. K. (2017, Januasry 17). Energy Efficient Electrical Household Appliances. (D.A.G.P.K. Gayathree, Interviewer).

Gustafsson, C. (2005). Trust as an instance of asymmetrical reciprocity: An ethics perspective on corporate brand management. Business Ethics: A European Review, 14, 142-150. https://doi.org/10.1111/j.1467-8608.2005.00398.x

Hair Jr, J. F., Hukt, G. M., Ringle, C. M., \& Sarstedt, M. (2014 a). A Primer on Partial Least Squares Structural Equation Modeling (PLS-SEM). Sage Publications Ltd.

Hair Jr, J. F., Sarstedt, M., Hopkins, L., \& Kuppelwieser, V. G. (2014 b). Partial least squares structural equation modeling (PLS-SEM) An emerging tool in business research. European Business Review, 26(2), 106-121. https://doi.org/10.1108/EBR-10-2013-0128

Hair, J. F., Sarstedt, M., Pieper, T. M., \& Ringle, C. M. (2012). The Use of Partial Least Squares Structural Equation Modeling in Strategic Management Research: A Review of Past Practices and Recommendations for Future Applications. Long Range Planning, 45(5-6), 320-340. https://doi.org/10.1016/j.lrp.2012.09.008

Hair, J. F., Sarstedt, M., Ringle, C. M., \& Mena, J. A. (2012 b). An assessment of the use of partial least squares structural equation modeling in marketing research. Journal of the Academic Marketing Science, 40, 
414-433. https://doi.org/10.1007/s11747-011-0261-6

Han, H., Hwangb, J., \& Lee, M. J. (2016). The value-belief-emotion-norm model: investigating customers' eco-friendly behaviour. $J$. of Travel \& Tourism Marketing. https://doi.org/10.1080/10548408.2016.1208790

Han, S., Nguyenb, B., \& Lee, T. (2015). Consumer-based chain restaurant brand equity, brand reputation, and brand trust. Inter. J. of Hospitality Management, 50, 84-93. https://doi.org/10.1016/j.ijhm.2015.06.010

Harland, P., Staats, H., \& Wilke, H. A. (1999). Explaining Pro environmental Intention and Behavior by Personal Norms and the Theory of Planned Behavior. Journal of Applied Social Psychology, 29(11), 2505-2528. https://doi.org/10.1111/j.1559-1816.1999.tb00123.x

Hartmann, P., Eisend, M., Apaolaza, V., \& D'Souza, C. (2017). Warm glow vs. altruistic values: How important is intrinsic emotional reward in pro environmental behavior? Journal of Environmental Psychology, 52, 43-55. https://doi.org/10.1016/j.jenvp.2017.05.006

Hassan, L., Shiu, E., \& Shaw, D. (2014). Who Says There is an Intention-Behaviour Gap? Assessing the Empirical Evidence of an Intention-Behaviour Gap in Ethical Consumption. Journal of Business Ethics. https://doi.org/10.1007/s10551-014-2440-0

He, H., Li, Y., \& Harris, L. (2012). Social identity perspective on brand loyalty. Journal of Business Research, 65, 648-657. https://doi.org/10.1016/j.jbusres.2011.03.007

Henseler, J., \& Chin, W. W. (2010). A Comparison of Approaches for the Analysis of Interaction Effects Between Latent Variables Using Partial Least Squares Path Modeling. Structural Equation Modeling, 17, 82-109. https://doi.org/10.1080/10705510903439003

Henseler, J., Hubona, G., \& Ray, P. A. (2016). Using PLS path modeling in new technology research: Updated guidelines. Industrial Management \& Data Systems, $116(1), \quad 2-20$. https://doi.org/10.1108/IMDS-09-2015-0382

Heshmat, S. (2014). Retrieved October 6, 2017, from https://www.psychologytoday.com/blog/science-choice/ 201412/basics-identity

Hitlin, S. (2003). Values as the Core of Personal Identity Drawing Links between Two Theories of Self. Social Psychology Quarterly, 66(2), 118-137. https://doi.org/10.2307/1519843

Holt, D. (2005). An Interview with Juliet Schor. Journal of Consumer Culture, 5(1), 5-21. https://doi.org/10.1177/1469540505049847

Hosany, S. (2011). Appraisal Determinants of Tourist Emotional Responses. Journal of Travel Research, 51(3), 303-314. https://doi.org/10.1177/0047287511410320

http://wwf.panda.org. (n. d.). Retrieved September 17, 2016, from http://wwf.panda.org/what_we_do/how_ we_work/our_global_goals/oceans/solutions/reducing_tourism_impact/difference_between_ecotourism_sus tainable_tourism.cfm

Hunt, S. D., \& Vitell, S. J. (2006). The General Theory of Marketing Ethics: A Revision and Three Questions. Journal of Macromarketing, 26, 143-153. https://doi.org/10.1177/0276146706290923

Hutter, K., \& Hoffmann, S. (2013). Carrotmob and Anti-consumption: Same Motives but Different Willingness to Make Sacrifices? J. of Macromarketing, 33(3), 217-231. https://doi.org/10.1177/0276146712470457

International Institute for Sustainable Development. (n. d.). Retrieved September 21, 2016, from http://www.iisd.org/topic/sustainable-development

Investopedia.com. (n. $\quad$ d.). Retrieved September $\quad 24, \quad 2016$, from http://www.investopedia.com/terms/p/perceived-value.asp

Israel, G. D. (1992). Determining Sample Size.

Kanchanapibul, M., Lacka, E., Wang, X., \& Chan, H. (2014). An empirical investigation of green purchase behaviour among the young generation. Journal of Cleaner Production, 66, 528-536. https://doi.org/10.1016/j.jclepro.2013.10.062

Kennedy, E. H., \& Kmec, J. (2018). Reinterpreting the gender gap in household pro-environmental behaviour. Environmental Sociology, 1-12. https://doi.org/10.1080/23251042.2018.1436891

Khare, A. (2015). Antecedents to green buying behaviour: A study on consumers in an emerging economy. Marketing Intelligence \& Planning, 33(3), 309-329. https://doi.org/10.1108/MIP-05-2014-0083 
Khare, A. (2015). Influence of green self-identity, past environmental behaviour and income on Indian consumers' environmentally friendly behaviour. Journal of Global Marketing Science, 25(4), 379-395. https://doi.org/10.1080/21639159.2015.1073423

Kim, Y. (2005). Antecedents of Green Purchase Behavior: An Examination of Collectivism, Environmental Concern, and PCE. Advances in Consumer Research, 32. Retrieved from https://www.researchgate.net/publication/233894746

Kim, Y. (2011). Understanding Green Purchase: The Influence of Collectivism, Personal Values and Environmental Attitudes, and the Moderating Effect of Perceived Consumer Effectiveness. Seoul Journal of Business, 17(1), 65-92. https://doi.org/10.35152/snusjb.2011.17.1.003

Kiviniemi, M. T., Ellis, E. M., Hall, M. G., Moss, J. L., Lillie, S. E., Brewer, N. T., \& Klein, W. M. (2017). Mediation, moderation, and context: Understanding complex relations among cognition, affect, and health behaviour. Psychology \& Health. https://doi.org/10.1080/08870446.2017.1324973

Knittel, Z., Beurer, K., \& Berndt, A. (2016). Brand avoidance among generation Y consumers. Qualitative Market Research: An International Journal, 19(1). https://doi.org/10.1108/QMR-03-2015-0019

Kollmuss, A., \& Agyeman, J. (2002). Why do people act environmentally and what are the barriers to pro-environmental behavior? Environmental Education Research, 239-260. https://doi.org/10.1080/13504620220145401

Kozinets, R., Handelman, J., \& Lee, M. (2010). Don't read this; or, who cares what the hell anti-consumption is, anyways? Consumption Markets \& Culture, 13(3), 225-233. https://doi.org/10.1080/10253861003786918

Kreibig, S. D. (2017). Computational reproducibility of "Goal relevance and goal conduciveness appraisals lead to differential autonomic reactivity in emotional responding to performance feedback" (Kreibig, Gendolla, \& Scherer, 2012): A guide and new evidence. International Journal of Psychophysiology. https://doi.org/10.1016/j.jpsycho.2017.06.001

Kumar, P. (2016). State of green marketing research over 25 years (1990-2014): Literature survey and $\begin{array}{lllll}\text { classification. Marketing Intelligence } \quad \& \quad \text { Planning, } & 34(1), & \text { 137-158. }\end{array}$ https://doi.org/10.1108/MIP-03-2015-0061

Kumar, S., \& Advani, J. (2005). Factors Affecting Brand Loyalty: A study in an emerging market on fast moving consumer goods. Journal of Customer Behaviour, 4, 251-275. https://doi.org/10.1362/1475392054797223

Kuo, Y., \& Feng, L. (2013). Relationships among community interaction characteristics, perceived benefits, community commitment, and oppositional brand loyalty in online brand communities. International Journal of Information Management, 33, 948- 962. https://doi.org/10.1016/j.ijinfomgt.2013.08.005

Ladhari, R., \& Tchetgna, N. (2015). The influence of personal values on Fair Trade consumption. Journal of Cleaner Production, 87, 469-477. https://doi.org/10.1016/j.jclepro.2014.10.068

Laroche, M., Bergeron, J., \& Barbaro-Forleo, G. (2001). Targeting consumer who are willing to pay more for environmentally friendly products. Journal of Consumer Marketing, 503-520. https://doi.org/10.1108/EUM0000000006155

Lau, G., \& Lee, S. (1999). Consumers' Trust in a Brand and the Link to Brand Loyalty. Journal of Market Focused Management, 341-370. https://doi.org/10.1023/A:1009886520142

Law, K. S., Wong, C., \& Mobley, W. H. (1998). Toward a Taxonomy of Multidimensional Constructs. The Academy of Management Review, 23(4), 741-755. https://doi.org/10.5465/amr.1998.1255636

Lee, H., \& Lyu, J. (2016). Personal values as determinants of intentions to use self-service technology in retailing. Computers in Human Behavior, 60, 322-332. https://doi.org/10.1016/j.chb.2016.02.051

Lee, M., \& Ahn, C. (2016). Anti-Consumption, Materialism, and Consumer Well-Being. The Journal of Consumer Affairs, 50(1), 18-47. https://doi.org/10.1111/joca.12089

Lee, M., Cherrier, H., \& Belk, R. (2013). Journal of Macromarketing Special Issue: Anti-Consumption Research and Society. Journal of Macromarketing, 33(3), 187-189. https://doi.org/10.1177/0276146713485964

Lee, M., Motion, J., \& Conroy, D. (2009). Anti-consumption and brand avoidance. Journal of Business Research, 169-180. https://doi.org/10.1016/j.jbusres.2008.01.024

Lehdonvirta, M., Lehdonvirta, V., \& Baba, A. (2011). Prosocial behaviour in avatar-mediated interaction: the influence of character gender on material versus emotional help-giving. On the Horizon, 19(3), 165-173. 
https://doi.org/10.1108/10748121111163878

Lewes, D. E. (2013, December 8). Retrieved September 17, 2016, from https://srilankawonderofasia.wordpress.com/tag/sri-lankan-tourism/

Li, H., Luo, X., Zhang, J., \& Xu, H. (2017). Resolving the Privacy Paradox: Toward a Cognitive Appraisal and Emotion Approach to Online Privacy Behaviors. Information and Management. https://doi.org/10.1016/j.im.2017.02.005

Marcussen, K. (2006). An application of identity-discrepancy theory. An application of identity-discrepancy theory, 49(1), 1-24. https://doi.org/10.1525/sop.2006.49.1.1

Marcussen, K., \& Gallagher, M. (2017). The Role of Aspirations and Obligations in Explaining the Relationship between Identity Discrepancies and Psychological Distress. Sociological Perspectives, 1-20. https://doi.org/10.1177/0731121417707754

McAdams, D. P. (2001). The Psychology of Life Stories. Review of General Psychology, 5(2), 100-122. https://doi.org/10.1037/1089-2680.5.2.100

Merriam Webster. (n. d.). Retrieved September 24, 2016, from http://www.merriam-webster.com/dictionary/ self $\%$ E2\%80\%93identity

Mills, B., \& Schleich, J. (2012). Residential Energy-Efficient Technology Adoption, Energy Conservation, Knowledge, and Attitudes: An Analysis of European Countries. Energy Policy, 49, 616-628. https://doi.org/10.1016/j.enpol.2012.07.008

Moors, A. (In Press). Appraisal theory of emotion. In V. Zeigler-Hill \& T. K. Shackelford (Eds.), Encyclopedia of Personality and Individual Differences. New York: Springer.

Moser, A. K. (2015). Thinking green, buying green? Drivers of pro-environmental purchasing behavior. Journal of Consumer Marketing, 32(3), 167-175. https://doi.org/10.1108/JCM-10-2014-1179

Mugo, F. W. (2002). Sampling in Research.

National Geographic Society. (2014). Greendex 2014: Consumer Choice and the Environment - A Worldwide Tracking Survey. National Geographic Society. Retrieved from http://images.nationalgeographic.com/ wpf/media-content/file/NGS_2014_Greendex_Highlights_FINAL-cb1411689730.pdf

Nielsen. (2014, June 17). Retrieved May 27, 2016, from http://www.nielsen.com/us/en/press-room/2014/ global-consumers-are-willing-to-put-their-money-where-their-heart-is.html

Oxford University Press. (n. d.). Retrieved from https://en.oxforddictionaries.com/definition/emotion

Papaoikonomou, E., \& Ryan, G. (2011). Towards a Holistic Approach of the Attitude Behaviour Gap in Ethical Consumer Behaviours: Empirical Evidence from Spain. International Advances in Economic Research, 17(1), 77-88. https://doi.org/10.1007/s11294-010-9288-6

Peter, P. C., \& Honea, H. (2012). Targeting Social Messages with Emotions of Change: The Call for Optimism. Journal of Public Policy \& Marketing, 31(2), 269-283. https://doi.org/10.1509/jppm.11.098

Polonsky, M. J. (1994). An Introduction to Green Marketing. Electronic Green Journal. Retrieved from http://www.greenprof.org/wp-content/uploads/2010/06/An-Introduction-to-Green-Marketing.pdf

Rezvania, Z., Janssona, J., \& Bengtsson, M. (2017). Cause I'll Feel Good! An Investigation into the Effects of Anticipated Emotions and Personal Moral Norms on Consumer Pro-Environmental Behavior. Journal of Promotion Management, 163-183. https://doi.org/10.1080/10496491.2016.1267681

Riel, A. C., Henseler, J., Kemény, I., \& Sasovova, Z. (2017). Estimating hierarchical constructs using consistent partial least squares: The case of second-order composites of common factors. Industrial Management \& Data Systems, 117(3), 459-477. https://doi.org/10.1108/IMDS-07-2016-0286

Ringle, C. M., \& Sarstedt, M. (2011). PLS-sem: Indeed a silver bullet. The Journal of Marketing Theory and Practice, 19(2), 139-151. https://doi.org/10.2753/MTP1069-6679190202

Roberts, J. A. (1996). Green Consumers in the 1990s: Profile and Implications for Advertising. Journal of Business Research, 36, 217-231. https://doi.org/10.1016/0148-2963(95)00150-6

Russell, J. A. (2009). Emotion, core affect, and psychological construction. Cognition and Emotion, 23(7), 1259-1283. https://doi.org/10.1080/02699930902809375

Russell, S., Young, C. W., Hardin, K., \& Robinson, C. (2017). Bringing Habits and Emotions into Food Waste 
Behaviour. Resources, Conservation and Recycling. https://doi.org/10.1016/j.resconrec.2017.06.007

Saidur, R., Masjuki, H. H., Jamaluddin, M. Y., \& Ahmed, S. (2007). Energy and associated greenhouse gas emissions from household appliances in Malaysia. Energy Policy, 35, 1648-1657. https://doi.org/10.1016/j.enpol.2006.05.006

Samarasinghe, G. D., \& Ahsan, F. J. (2014). Impact of Consumers' Moral Self- Identity on Green Purchase Decisions of Fast Moving Consumable Goods (FMCG). Colombo Business Journal, 5(1), 1-15.

Samarasinghe, G. D., \& Samarasinghe, D. S. (2013). Green decisions: consumers' environmental beliefs and green purchasing behaviour in Sri Lankan context. Int. J. Innovation and Sustainable Development, 7(2), 172-184. https://doi.org/10.1504/IJISD.2013.053336

Scherer, K. R. (1997). Profiles of Emotion-antecedent Appraisal: Testing Theoretical Predictions across Cultures. Cognition and Emotion, 11(2), 113-150. https://doi.org/10.1080/026999397379962

Scherer, K. R. (2005). What are emotions? And how can they be measured? Social Science Information, 44(4), 695-729. https://doi.org/10.1177/0539018405058216

Scherer, K. R. (2009 a). The dynamic architecture of emotion: Evidence for the component process model. Cognition \& Emotion, 23(7), 1307-1351. https://doi.org/10.1080/02699930902928969

Scherer, K. R. (2009 b). Emotions are emergent processes: They require a dynamic computational architecture. Philosophical Transactions of the Royal Society, architecture, 3459-3474. https://doi.org/10.1098/rstb.2009.0141

Schwartz, D., \& Loewenstein, G. (2017). The Chill of the Moment: Emotions and Pro-environmental Behavior. Journal of Public Policy \& Marketing, 52(5), 657-673. https://doi.org/10.1509/jmr.10.0219

Schwartz, S. (2012). An Overview of the Schwartz Theory of Basic Values. Online Readings in Psychology and Culture, 2(1). https://doi.org/10.9707/2307-0919.1116

Sheth, J. N., Sethia, N. K., \& Srinivas, S. (2012). Mindful consumption: a customer-centric approach to sustainability. J. of the Academic Marketing Science, 39, 21-39. https://doi.org/10.1007/s11747-010-0216-3

Shiffman, L. G., Wisenblit, J., \& Kumar, S. R. (2015). Consumer Behavior (Vol. 11). New Delhi: Dorling Kindersley (India) Pvt. Ltd.

Shin, H., Casidy, R., Yoon, A., \& Yoon, S. (2016). Brand trust and avoidance following brand crisis: A quasi-experiment on the effect of franchisor statements. Journal of Brand Management. https://doi.org/10.1057/s41262-016-0011-7

Smith, C. A., \& Lazarus, R. S. (1990). Emotion and Adaptation. In L. A. Pervin (Ed.), Handbook of Personality: Theory and Research (pp. 609-637). New York: Guilford. Retrieved from http://people.ict.usc.edu/ gratch/CSCI534/Readings/Smith\&Lazarus90.pdf

So, J., Achar, C., Han, D., Agrawal, N., Duhachek, A., \& Maheswaran, D. (2015). The psychology of appraisal: Specific emotions and decision-making. Journal of Consumer Psychology, 25(3), 359-371. https://doi.org/10.1016/j.jcps.2015.04.003

Sri Lanka Sustainable Energy Authority. (n. d.). Retrieved from http://www.energy.gov.lk/your-life/your-home/reduce-your-carbon-footprint

Steg, L., \& Vlek, C. (2009). Encouraging pro-environmental behaviour: An integrative review and research agenda. Journal of Environmental Psychology, 29. https://doi.org/10.1016/j.jenvp.2008.10.004

Straughan, R. D., \& Roberts, J. A. (1999). Environmental segmentation alternatives: A look at green consumer behavior in the new millennium. Journal of Consumer Marketing, 16(6), 558-575. https://doi.org/10.1108/07363769910297506

Strong, C. (1996). Features contributing to the growth of ethical consumerism - a preliminary investigation. Marketing Intelligence \& Planning, 14(5), 5-13. https://doi.org/10.1108/02634509610127518

Stryker, S., \& Burke, P. J. (2000). The Past, Present, and Future of an Identity Theory. Social psychology quarterly, 284-297. https://doi.org/10.2307/2695840

Stryker, S. (2004). Integrating Emotion in to Identity Theory. In J. H. Turner (Ed.), Theory and Research on Human Emotions (pp. 1-23). Emerald Group Publishing Limited. https://doi.org/10.1016/S0882-6145(04)21001-3 
Sudbury-Riley, L., \& Kohlbacher, F. (2016). Ethically minded consumer behavior: Scale review, development, and validation. Journal of Business Research, 69, 2697-2710. https://doi.org/10.1016/j.jbusres.2015.11.005

Tam, K., \& Chan, H. (2017). Environmental concern has a weaker association with pro-environmental behavior in some societies than others: A cross-cultural psychology perspective. Journal of Environmental Psychology, 53, 213-223. https://doi.org/10.1016/j.jenvp.2017.09.001

The Institute of Grocery Distribution. (n. d.). Retrieved September 10, 2016, from http://www.igd.com/Research/Sustainability/Ethical-consumerism/

The World Bank Group. (2018). Retrieved from https://data.worldbank.org/country/sri-lanka

Wang, X. (2016). Risk perceptions, moral attitudes, and anticipated guilt in US consumers' climate change behavioral intentions. Journal of Risk Research. https://doi.org/10.1080/13669877.2016.1179213

Wesley, S. C., Lee, M., \& Kim, E. Y. (2012). The Role of Perceived Consumer Effectiveness and Motivational Attitude on Socially Responsible Purchasing Behavior in South Korea. Journal of Global Marketing, 25(1), 29-44. https://doi.org/10.1080/08911762.2012.697383

Whitmarsh, L., \& O'Neill, S. (2010). Green identity, green living? The role of pro-environmental self-identity in determining consistency across diverse pro-environmental behaviours. Journal of Environmental Psychology, 30, 305-314. https://doi.org/10.1016/j.jenvp.2010.01.003

World Bank. (n. d.). World Bank. Retrieved August 1, 2016, from http://data.worldbank.org/country/sri-lanka?view=chart

Yang, Z., Fan, Y., \& Zheng, S. (2016). Determinants of household carbon emissions: Pathway toward $\begin{array}{llll}\text { eco-community in } \text { Beijing. Habitat International, } & \text { 57, }\end{array}$ https://doi.org/10.1016/j.habitatint.2016.07.010

Young, W., Hwang, K., McDonald, S., \& Oates, C. (2010). Sustainable Consumption: Green Consumer Behaviour when Purchasing Products. Sustainable Development, 18, 20-31. https://doi.org/10.1002/sd.394

Zhao, X., Lynch, J. G., \& Chen, Q. (2010). Reconsidering Baron and Kenny: Myths and Truths about Mediation Analysis Reconsidering Baron and Kenny: Myths and Truths about Mediation Analysis. Journal of Consumer Research, 37(2), 197-206. https://doi.org/10.1086/651257

\section{Copyrights}

Copyright for this article is retained by the author(s), with first publication rights granted to the journal.

This is an open-access article distributed under the terms and conditions of the Creative Commons Attribution license (http://creativecommons.org/licenses/by/4.0/). 